\title{
Marek Sobczyński \\ Zmiany granic w Afryce na przełomie XX i XXI wieku
}

\begin{abstract}
W artykule zaprezentowano zmiany granic w Afryce w ostatniej dekadzie XX w. oraz pierwszym piętnastoleciu XXI w., czyli w okresie wielkich transformacji ustrojowych związanych z zanikiem bipolarnego podziału świata i upadkiem systemu komunistycznego. W Afryce okres ten wiązał się $\mathrm{z}$ wyzwoleniem się kilkunastu państw spod radzieckiej dominacji politycznej, odrzuceniem systemu socjalistycznego w ekonomice i powrotem do wolnorynkowej gospodarki kapitalistycznej. Zakwestionowano także zasadę nienaruszalności granic państwowych w Afryce. W omawianym okresie następowały liczne zmiany granic politycznych, przeprowadzane zarówno na drodze pokojowej, przy mediacji organizacji międzynarodowych, jak i na drodze zbrojnej; te jednak nadal nie znajdują akceptacji społeczności międzynarodowej i rzadko kończą się powodzeniem w dłuższej perspektywie.
\end{abstract}

Słowa kluczowe: granice, konflikty, stosunki międzynarodowe, Afryka.

\section{Wprowadzenie}

Początek XX w. był dla Afryki okresem jej zintensyfikowanej kolonizacji i ostatecznego podziału całego niemal kontynentu pomiędzy państwa imperialne. W tym wieku przetoczyły się przez Afrykę dwie wojny światowe, choć druga dotknęła jej w dużo większym stopniu niż pierwsza. Dla Afrykanów druga wojna światowa wybuchła 3 października 1935 r., wraz w wkroczeniem wojsk włoskich do Etiopii. Połowa XX w. była dla Afryki okresem uzyskiwania niepodległości przez kolonie państw imperialnych, a 1960 r. był apogeum tego procesu. Przez całą drugą połowę ubiegłego wieku w Afryce panowało przekonanie, wzmacniane przez akty prawnomiędzynarodowe uchwalane na forum ONZ i OJA, o nienaruszalności granic afrykańskich, jakkolwiek wykazano już, że de facto granice te nie były nienaruszalne. Jednak dopiero ostatnia dekada XX w. miała się okazać okresem weryfikacji tej tezy i przyniosła zmiany granic pomiędzy państwami afrykańskim, co, jak przypuszczano, może prowadzić do wojen. I rzeczywiście doprowadziło! Wojny te wpisały się w narastający konflikt światowy, nazwany przez S. Huntingtona (1993) zderzeniem cywilizacji. 
Kwestia zmienności granic w Afryce rozpatrywana jest szeroko, dotyczy przede wszystkim zmian granic międzynarodowych, ale w niektórych przypadkach także granic państwowych wewnątrz państw federacyjnych lub o zróżnicowanym ustroju terytorialnym.

\section{Zmiany granic po Jesieni Ludów i na początku XXI w.}

Jesień Ludów to ciąg wydarzeń politycznych, zapoczątkowanych obaleniem komunizmu w Polsce, w czerwcu 1989 r., który objął głównie państwa Europy Środkowo-Wschodniej. Jednak fakt, że wynikiem tego procesu był upadek komunizmu, rozpad imperium radzieckiego i zakończenie dualistycznego podziału świata $\mathrm{z}$ okresu zimnej wojny, miały przełożenie na stosunki międzynarodowe na całym świecie, Afryki nie wyłączając. Uzasadnione jest więc ustanowienie cezury 1990 r., kiedy ustało komunistyczne oddziaływanie na stosunki międzynarodowe w Afryce, które leżało u podstaw co najmniej kilku dużych konfliktów na tym kontynencie. Wszystkie komunistyczne państwa afrykańskie w ciągu kilku pierwszych lat ostatniej dekady XX w. odrzuciły ideologię komunistyczną, choć $\mathrm{w}$ większości $\mathrm{z}$ nich nie nastąpiła zmiana elit politycznych. Zakończenie zimnej wojny pozwoliło przyspieszyć kilka już trwających w Afryce procesów, ale uruchomiło też sporą liczbę nowych.

\subsection{Afryka Południowa}

Decydujący wpływ miał upadek komunizmu na sytuację w Namibii i całej Afryce Południowej. Zarządzająca Afryką Południowo-Zachodnią - Namibią RPA zdecydowała się na ostateczną rezygnację $\mathrm{z}$ kontroli nad tą prowincją. De facto zaakceptowała, po niemal pół wieku, prawo ONZ do powiernictwa nad tym terytorium i przekazała tej organizacji administrację nad Namibią. Organizacja ta utworzyła Grupę NZ ds. Pomocy w Okresie Przejściowym (UNTAG) (Calvocoressi 2002, s. 717).

Pod egidą ONZ przeprowadzono wybory w 1989 r., które przyniosły zwycięstwo SWAPO, organizacji narodowo-wyzwoleńczej najliczniejszego plemienia Owambo, która odrzuciła jednak ideologię komunistyczną i 21 marca 1990 r. proklamowano niepodległość Republiki Namibii (Namibia ... 1991, s. 4). Nowe władze zrezygnowały z autonomii plemiennych homelandów i ustanowiły ustrój unitarny, zmieniając 31 sierpnia 1992 r. podział administracyjny kraju (Sobczyński 2006, s. 331).

Nie rozstrzygnięto jednak losów południowoafrykańskiej eksklawy Zatoki Wielorybiej (Walvis Bay) i przybrzeżnych wysepek, które nie zostały zwrócone Namibii w chwili jej niepodległości. W toku dalszych rokowań uzgodniono 
przekazanie, od 15 stycznia 1993 r., Zatoki Wielorybiej i 12 przybrzeżnych Wysp Penguin pod wspólną administrację (kondominium) Namibii i RPA (Transfer... 1994) (ryc. 1). Wspólne władze administracyjne Portu Walvis Bay i Wysp Penguin przygotowywały przejęcie terytorium przez Namibię. Tym niemniej ponownie granica eksklawy zmieniła charakter na wewnątrznamibijską. Tę cechę utraciła jednak 1 marca 1994 r., wraz z przyłączeniem całego terytorium do Namibii (The history of Walvis Bay... 2005). W podziale administracyjnym Namibii całkowicie zatarto granice eksklawy.
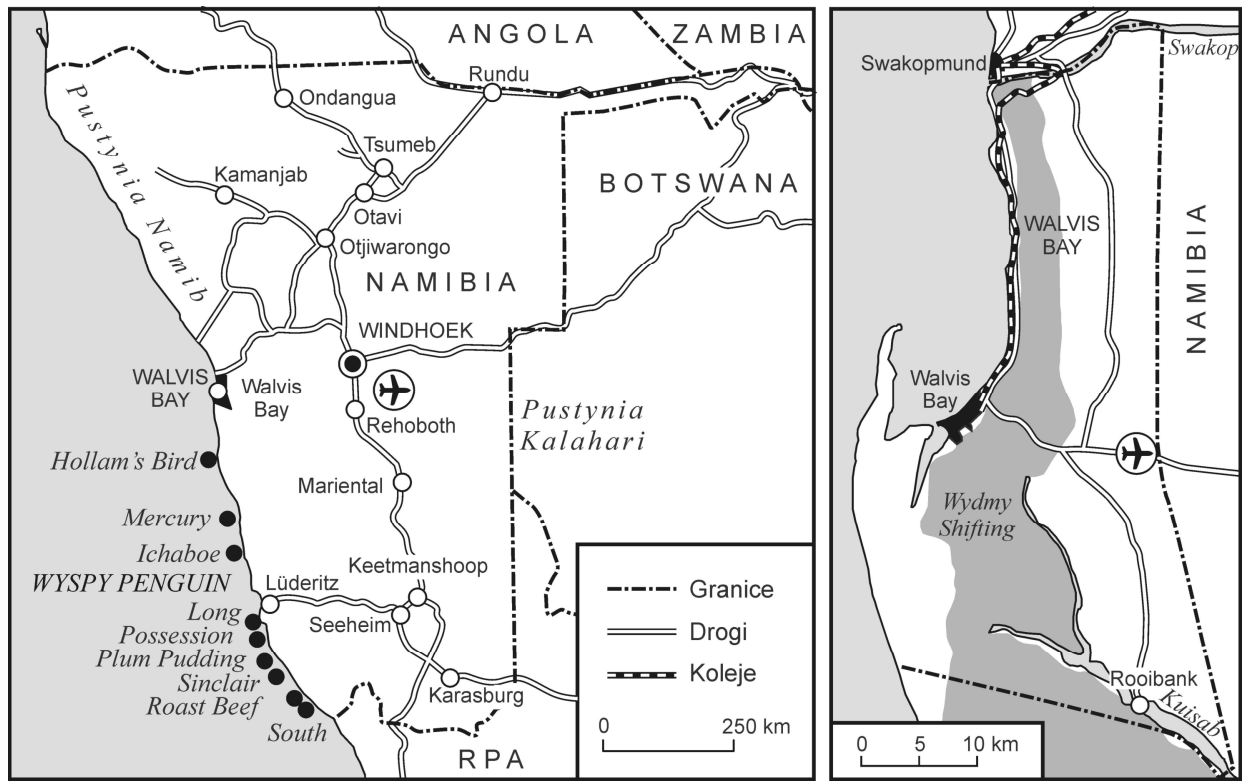

Ryc. 1. Kondominium południowoafrykańsko-namibijskie Walvis Bay i Wysp Penguin Źródło: M. Sobczyński (2006, s. 331)

Z upadkiem systemu komunistycznego zbiegło się w czasie zakończenie rządów rasistowskich w Południowej Afryce. Miało to swoje przełożenie na granice wewnętrzne w RPA, gdy 27 kwietnia 1997 r. zlikwidowano quasi-niepodległe homelandy. Wprowadzono całkowicie nowy podział administracyjny kraju, na dziewięć prowincji, przy jednoczesnej likwidacji ustroju federacyjnego (Sobczyński 2006, s. 370). Dawne granice prowincji, jeśli gdzieś nadal się utrzymały w ramach nowego podziału, nie miały już rangi wyższej niż granice administracyjne państwa unitarnego. 


\subsection{Afryka Wschodnia}

Upadek komunizmu w Afryce nie wszędzie przyniósł zmiany na lepsze. Jednym z przykładów pogorszenia się sytuacji geopolitycznej w regionie jest tzw. Róg Afryki. Szczególnym przypadkiem upadku państwa po obaleniu komunizmu jest Somalia. Lewicowy dyktator tego państwa został obalony 26 stycznia 1991 r. (Orłowska 1999, s. 308). Zaraz jednak doszło do walk frakcji polityczno-plemiennych i rozpadu Somalii na strefy wpływów poszczególnych frakcji. Aby uchronić północną część kraju przed chaosem, lokalne władze na obszarze byłej kolonii brytyjskiej proklamowały 7 czerwca 1991 r. niepodległość Republiki Somalilandu (Saleh Bali 1996) (ryc. 2).

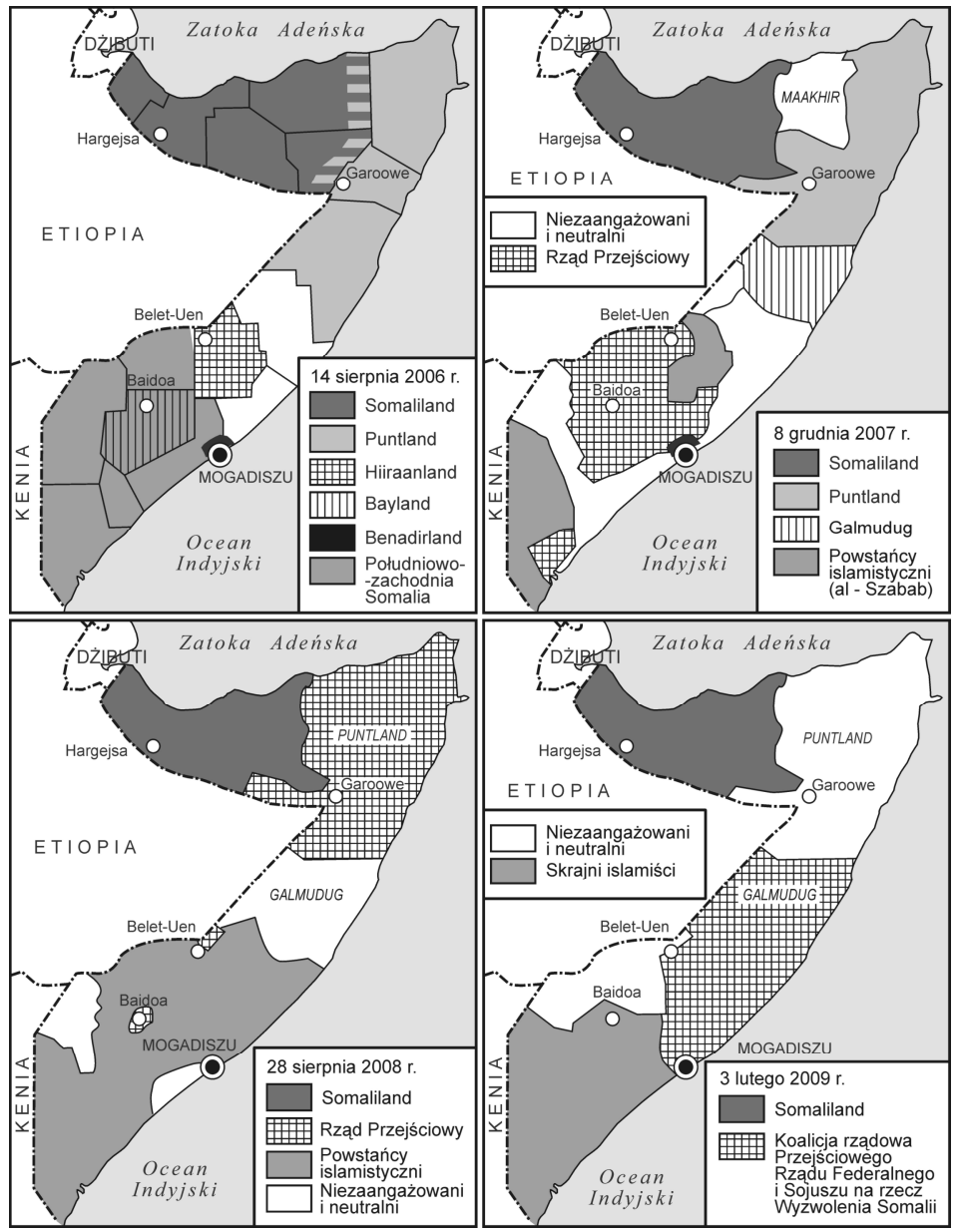

Ryc. 2. Dezintegracja Somalii w latach 2006-2009

Źródło: opracowanie własne na podstawie: P. Boniface (2001, s. 142), M. Sobczyński (2006, s. 234), Somalia report (2015) 
Paradoksem jest, że społeczność międzynarodowa i jej organizacje, w tym ONZ, uznają nadal faktycznie nieistniejącą, zdezintegrowaną terytorialnie Somalię i jej rząd pozbawiony realnej władzy nad całością kraju, a odmawiają uznania Somalilandu, faktycznie istniejącego, powstałego na drodze pokojowej, bez obcej interwencji i rządzonego demokratycznie (Podeszwa 1999, s. 318).

W obliczu tragedii wojny domowej, ONZ wysłał do Somalii w 1992 r. siły pokojowe, których misja zakończyła się w 1995 r. całkowitą klęską (Traditional governance... 2005, s. 5). Dezintegracja Somalii postępowała nadal, 29 lipca 1998 r., w północno-zachodniej części byłego Somali Włoskiego proklamowano secesję regionu Puntland (Puntland... 2003), którego przywódcy ogłosili wolę stworzenia, na bazie tego nowego państwa, przyszłej demokratycznej federacji. Wyrazem tej woli było przemianowanie regionu, od 18 czerwca 2012 r., na Somalijskie Państwo Puntland (ryc. 3).

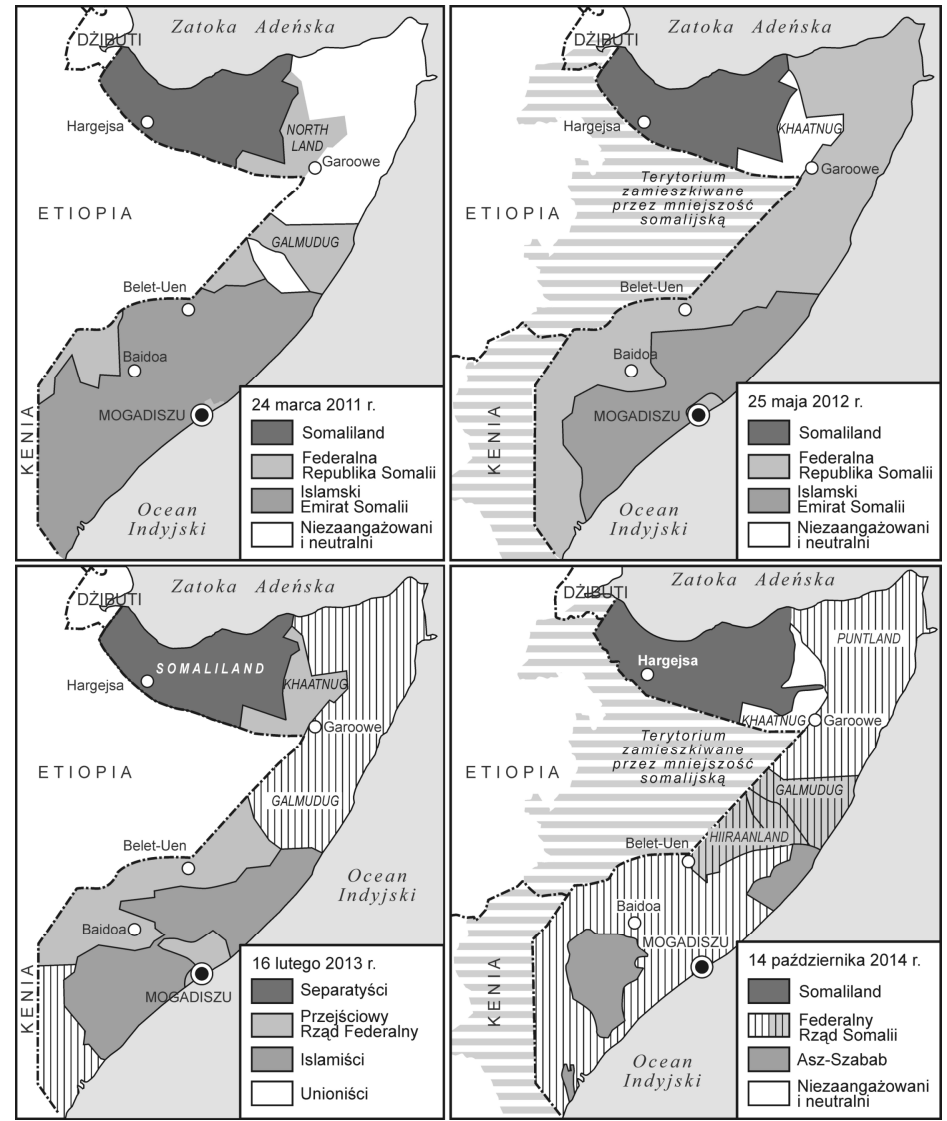

Ryc. 3. Dezintegracja Somalii w latach 2010-2015 Źródło: opracowanie własne na podstawie: Somalia report (2015), Somali civil war (2015), War in Somalia (2015) 
Na południu Somalii, 3 września 1998 r., pojawiło się efemeryczne państwo Dżubaland, później w jego miejsce 3 kwietnia 2011 r. powołano region Azania, a następnie 15 maja 2013 r. ustanowiono Somalijskie Państwo Dżubaland (Hirad 2013, s. 1).

W 2000 r. rozpoczęto w Dżibuti rokowania mające na celu zjednoczenie wszystkich klanów i prowincji Somalii oraz wyłonienie rządu jedności narodowej, tam też zebrał się po 10 latach przerwy parlament somalijski, który pod koniec roku wyłonił rząd. Organowi temu nie było jednak dane objąć władzy w stolicy, która pozostała w rękach jednej z frakcji nieuznających ustaleń z Dżibuti. Frakcja ta zdołała natomiast poszerzyć swoje władanie przez podbój Dżubalandu. W 2001 r. doszło dodatkowo do wojny pomiędzy Somalilandem i Puntlandem, a także do wojny domowej w samym Puntlandzie (Boniface 2001, s. 142-143).

Dalsza dezintegracja dokonała się wraz z ogłoszeniem 19 marca 2001 r. autonomii Banadirlandu (w praktyce jest to aglomeracja Mogadiszu), a 1 kwietnia 2002 r. Państwa Południowo-Zachodniej Somalii, znanego także jako Przejściowa Administracja Południowego Zachodu, założona przez przywódców Armii Oporu Rahanwejn, kontrolująca prowincje Bay oraz Bakool (Warsame 2002). W lutym 2003 r. powstało w części tego obszaru kolejne państwo - Bayland. W 2004 r. pokojowe rozmowy przeniesiono z Dżibuti do Nairobi, gdzie ponownie udało się wyłonić rząd jedności narodowej, a nawet wybrać prezydenta Somalii (został nim zwycięski w wojnie domowej prezydent Puntlandu), ale wizyta tych władz w kraju w marcu 2005 r. zakończyła się niewpuszczeniem ich do stolicy przez frakcje nadal nieuczestniczące w rokowaniach pokojowych (Sobczyński 2006, s. 233-234).

\section{Zmiany granic w ostatniej dekadzie na tle wojny ze światowym terroryzmem}

\subsection{Afryka Wschodnia}

Od 2006 r. na scenie konfliktu somalijskiego pojawiła się nowa siła, islamiści z Unii Trybunałów Islamskich, kontrolująca dużą część południa Somalii. Uznane międzynarodowo tymczasowe władze Somalii zostały wsparte militarnie przez Etiopię, której wojska w lipcu 2006 r. wkroczyły do Somalii w celu odbicia Baidoa, gdzie miał się ulokować somalijski rząd tymczasowy, wobec pozostawania Mogadiszu w rękach islamistów (Elmi 2015, s. 28). Do lutego 2007 r. wojska etiopskie wyparły islamistów z dużej części Somalii, przywracając kontrolę rządu nad Mogadiszu. Na mocy decyzji ONZ i Unii Afrykańskiej do Somalii przybyły w marcu 2007 r. międzynarodowe siły pokojowe AMISOM 
(złożone z wojsk państw afrykańskich: Ugandy, Burundi, Nigerii, Dżibuti, Ghany, Sierra Leone, Kenii i Malawi) (Williams 2013, s. 2).

Islamiści po klęsce militarnej dokonali przegrupowania, tworząc terrorystyczną organizację asz-Szabab, organizację powiązaną początkowo z al-Kaidą, a ostatnio z Państwem Islamskim. Odzyskiwali stopniowo kontrolę nad południem i centralną częścią Somalii, a od kwietnia 2008 r. rozpoczęli ponownie łączenie kontrolowanych obszarów, osiągając, po wycofaniu się w styczniu 2009 r. wojsk etiopskich, niemal pełną kontrolę nad południową połową kraju. Doszło wówczas do rozłamu pośród islamistów, gdyż prezydentem Somalii został przedstawiciel Unii Trybunałów Islamskich, co skłoniło asz-Szabab oraz nową radykalną siłę islamską Hizb al-Islam do zwalczania sił dążących do zjednoczenia Somalii. W 2009 r. islamiści zdobyli pograniczną z Etiopią prowincję Bakool i ponownie zaatakowali Mogadiszu. Islamiści wsparci przez zagraniczne ośrodki terrorystyczne ogłosili nowy plan polityczny budowy Wielkiej Somalii, obejmującej wszystkie obszary zamieszkane przez muzułmanów w Somalii, Etiopii i Kenii. Nie powstrzymało ich nawet wprowadzenie przez rząd tymczasowy w Somalii szariatu i nadal dążą do obalenia rządu i wyparcia sił pokojowych. W odwecie za udział w siłach pokojowych somalijscy islamiści dokonują ataków terrorystycznych w Ugandzie, Kenii. Od października 2009 r. trwają też walki pomiędzy oboma ugrupowaniami islamistycznymi na południu kraju. Niezależnie od sił pokojowych, od 16 października 2011 r. interwencję na południu Somalii podjęły również wojska kenijskie, zajmując Azanię i pomniejszając obszar kontrolowany przez islamistów. W 2012 r. wprowadziła wojska do Somalii także Etiopia. We wrześniu 2012 r. zjednoczone siły wspierające rząd tymczasowy podjęły ofensywę przeciwko islamistom w rejonie Kismaju na południu kraju, zajmując do 22 września to ostatnie duże miasto pozostające w ich rękach. Od tego czasu islamiści przeszli do walk rozproszonych, dzięki czemu skutecznie atakują siły rządowe i ich sojuszników na niemal połowie obszaru Somalii, efektywnie kontrolując jednak jedynie niewielkie fragmenty, w tym część Mogadiszu. Coraz częściej jednak organizują udane i spektakularne zamachy terrorystyczne w innych państwach regionu, przede wszystkim w Kenii (Somalia: al-Shabaab... 2014). W trakcie somalijskiej wojny domowej nadal trwał rozpad jej struktur terytorialnych i wybuchały lokalne wojny pomiędzy nowymi jednostkami politycznymi tam tworzonymi.

Od samego początku istnienia Somalilandu, którego wschodnią granicą była dawna granica brytyjsko-włoska $\mathrm{z}$ okresu kolonialnego, stała się ona przedmiotem sporu z Puntlandem. Ponownie więc doszło do zakwestionowania granic odziedziczonych po epoce kolonialnej, choć w tym przypadku przez pierwsze trzy dekady niepodległości ta granica nie istniała. Spór toczony od 2004 r. dotyczył trzech okręgów somalijskich: Sool, Sanaag i Cayn (Hoehne 2007). Wyko- 
rzystując niejasną sytuację polityczną, lokalni wodzowie klanów podejmowali liczne próby utworzenia pomiędzy Somalilandem i Puntlandem odrębnych państewek. Pierwszego lutego 2007 r. proklamowano powstanie niepodległego państwa Maakhir w prowincji Sanaag, które ostatecznie w styczniu 2009 r. przyłączono do Puntlandu. Pierwszego października 2007 r. wybuchła, koło Laascaanood (Las Anod) w okręgu Sool, wojna graniczna Somalilandu i Puntlandu, zakończona 15 października utrzymaniem przez Somaliland kontroli nad tym regionem. Pierwszego maja 2008 r. ogłoszono też niepodległość Somalijskiego Państwa Northlandu, utworzonego z tych samych prowincji, choć w innym kształcie terytorialnym niż Maakhir. W styczniu 2009 r. obszar ten został jednak zajęty przez Somaliland i Puntland, a jego państwowość zlikwidowano. Po sukcesach wojsk Puntlandu w 2011 r. na części terytorium ponownie ujawnił się rząd Northlandu, ale pod nową nazwą Sool-Sanaag-Cayn (SSC), kontynuujący konflikt z Somalilandem. Kolejną państwowość na tym obszarze proklamowano 1 stycznia 2012 r. pod nazwą Somalijskie Państwo Khaatumo, ze stolicą w Laascaanood, pozostającą zresztą nadal pod kontrolą Somalilandu (Somalia: Puntland's... 2013); 14 kwietnia 2014 r. wojska Somalilandu zajęły Taleh, tymczasową stolicę Khaatumo, rozbijając to państwo na dwie części terytorialne (Hoehne 2015, s. 157). W 2015 r. Khaatumo odzyskało ciągłość przestrzenną, lecz nadal bez Talehu. Jak się można domyślać, większość jednostek tworzonych w tym rejonie Somalii jest organizowana przez Puntland w celu destabilizacji Somalilandu, jedynego demokratycznego państwa w regionie.

Somaliland ma też kłopoty $\mathrm{z}$ własnymi separatystami w zachodniej prowincji Awdal, którzy 14 lutego 2007 r. proklamowali Republikę Awdal, a 8 września 2009 r. Somalijskie Państwo Adal, deklarując wolę przyłączenia się do federacji somalijskiej. Jak dotąd rząd Somalilandu kontroluje prowincję, a zatem podane akty mają wymiar jedynie deklaratywny (Awdal ,,Republic”... 2007, The declaration... 2009).

Na południowym krańcu Puntlandu granica nie była stabilna i tu również powstało kilka, niekiedy efemerycznych, jednostek geopolitycznych. Niektóre $\mathrm{z}$ nich proklamowano w Nairobi, w Kenii, a zatem trudno ocenić, na ile na obszarach, do których te proklamacje się odnosiły, doszło do efektywnego ustanowienia ich jurysdykcji. Pierwsze próby ogłoszenia przez klan Hawdale autonomii Hiiraanu, jak się wydaje nieudane, podjęto już w 1998 r. W Hiiraanie pojawiła się w 2005 r. kolejna jednostka polityczna - Midland, kreowana w obecności wojsk etiopskich. Ostatecznie 13 lipca 2010 r. ogłoszono powstanie Państwa Hiiraan, w środkowej części Somalii, przy granicy z Etiopią. Powiększenie jego powierzchni udało się 9 sierpnia 2015 r. dzięki połączeniu Hiiraanu i części prowincji Szabelle, przekształconych w nowe Somalijskie Państwo 
Hiiraan oraz Środkowe Szabelle (Federal gov't... 2015). W prowincji Dolne Szabelle somalijska ludność Bantu proklamowała 1 października 2011 r. autonomię Jiin Webi.

W środkowosomalijskich prowincjach Galguduud i Mudug 14 sierpnia 2006 r. powołano państwo Somalijskie Państwo Galmudug. W części tego obszaru, 9 września 2009 r., ogłoszono powstanie autonomicznej wspólnoty Mareeg, która swoim obszarem i tradycją nawiązuje do XVI-wiecznego sułtanatu Ujuuraan. Jednostka ta upadła 18 września 2009 r., lecz została ponownie restytuowana 9 sierpnia 2011 r. i nadal istnieje (Mareeg State... 2015). W tej samej przestrzeni rząd federalny ogłosił 20 lipca 2014 r. powstanie przyszłego stanu federacji somalijskiej, nazwanego Somalijskie Państwo Regionów Środkowych.

Na południu Somalii, poza wspomnianymi już jednostkami w Dżubie, powołano w 2008 r. także Maayland, zwany też Unią Południowej Somalii. W Nairobi 31 grudnia 2010 r. ogłoszono powstanie jednostki politycznej Dżuba Dżazira. W Skandynawii pojawiły się enuncjacje o proklamowaniu 8 stycznia 2011 r., wokół Ras Kamboi, jednej ostatnich twierdz islamistów, jednostki geopolitycznej Dżuba Ras. Istniało również Regionalne Państwo Doliny Dżuby. Ogłoszono także 5 lipca 2011 r. połączenie administracji prowincji Dżuba i Szabelle.

Większość z tych bytów politycznych, o ile rzeczywiście realnie funkcjonowała w przestrzeni kraju, była efemerydami. Tam gdzie pojawiała się jednak efektywna jurysdykcja tych rządów, powstawały też państwowe granice, które zależnie od stanu stosunków pomiędzy tymi jednostkami można określić jako granice wewnątrzfederacyjne lub linie demarkacyjne stron walczących.

Pomiędzy niektórymi jednostkami doszło do uzgodnień o działaniu na rzecz federalizacji Somalii. Układ taki zawarły 14 października 2014 r. Puntland i rząd federalny w Mogadiszu. Rozwiązanie to popiera Unia Afrykańska i niektóre inne jednostki polityczne Somalii, a przeciwny jest Somaliland, który od prawie ćwierć wieku cieszy się faktyczną suwerennością i utrzymuje ład społeczny (Morland 2014).

Rozwiązań konfliktu w Somalii może być wiele. Jednym z przykładów jest projekt federalizacji kraju przygotowany przez ekspertów etiopskich, dzielący Somalię na sześć dużych autonomicznych regionów: Somaliland, Puntland, Regiony Środkowe, Hiiraan i Środkowe Szabelle, Południowo-Zachodni i Dżubaland. Cechuje je wszystkie dostęp do morza i... wspólna granica z Etiopią (Elmi 2015, s. 5).

Skutkiem upadku komunizmu było zwycięstwo sił prozachodnich w Etiopii. Trwała tam już od 1984 r. wojna domowa, w trakcie której zjednoczyły się zwalczające reżim komunistyczny partyzantki etniczne: amharska, tigrajska oraz 
erytrejska (Mantel-Niećko 1999, s. 195). Warunkiem utrzymania tego sojuszu było uzgodnienie, że mniejszości otrzymają prawo do autonomicznych prowincji w przyszłej federacji etiopskiej, a Erytrea będzie mogła nawet z niej wystąpić, o ile taka będzie wola jej mieszkańców. W maju 1991 r. siły prozachodnie obaliły w Etiopii komunizm. W Erytrei, której część północna już od $1981 \mathrm{r}$. była wyzwolona od wojsk etiopskich w toku wojny domowej, przeprowadzono w 1993 r. referendum, w którym większość mieszkańców opowiedziała się za niepodległością kraju. Republikę Erytrei proklamowano 29 maja 1991 r., ale światowe uznanie uzyskała po referendum z 24 maja 1993 r. (Hartleb-Wroczyńska 1999, s. 265).

Dla Etiopii uznanie państwowości Erytrei był bardzo bolesne, bo znalazła się w gronie 45 państw świata pozbawionych dostępu do morza i piątym państwem, które traci niego dostęp (po Boliwii, Austrii, Węgrzech i Serbii), co jak wiadomo z praktyki jest wielkim obciążeniem dla gospodarki kraju. Granica erytrejsko-etiopska stała się granicą międzynarodową, a jej przebieg zakwestionowały natychmiast obie strony. Doprowadziło to do wojny granicznej 6 maja 1998 r., kiedy wojska erytrejskie zaatakowały terytorium Etiopii na wschód od miasta Badme (Boniface 2001, s. 140-141) (ryc. 4). Etiopia, będąca jedną z potęg militarnych Afryki, odpowiedziała ofensywą, podczas której do 27 lutego $1999 \mathrm{r}$. zajęła pas ok. $10 \mathrm{~km}$ terytorium Erytrei, zmuszając ją do zawarcia rozejmu. Próba zdobycia przez Etiopczyków 16 maja tego roku spornej miejscowości Tsorona była nieudana. Po dwóch latach ponowna ofensywa etiopska 12 maja 2000 r. w regionie Shambuko i Mandefera doprowadziła do przekroczenia rzeki Mareb oraz przecięcia głównej drogi zaopatrzeniowej Erytrei. Objęte międzynarodową infamią strony, w geście dobrej woli wycofały się 23 maja tego roku z linii frontu na odcinku koło Zalambessy, 100 km od stolicy Erytrei Asmary; 25 maja 2000 r. Erytrea zgodziła się na podjęcie rokowań pokojowych, kiedy armia etiopska kontrolowała już około ćwierci jej terytorium.

Porozumienie pokojowe podpisano w Algierze 12 grudnia $2000 \mathrm{r}$. Wyrażono zgodę, aby przekazać delimitację granicy komisji międzynarodowej. Obecnie pas graniczny, o szerokości $25 \mathrm{~km}$, jest zdemilitaryzowany i kontrolowany przez siły ONZ, ale konflikt nie został zakończony, a granica ostatecznie wyznaczona (Peace agreements... 2000). Komisja wydała wprawdzie werdykt 13 kwietnia 2002 r., ale Erytrea go odrzuciła i zażądała powołania nowej komisji. Wyrok MTS z 21 grudnia 2005 r. głosił, że Erytrea, atakując Etiopię, złamała prawo międzynarodowe. Od 2006 r. oba państwa bojkotują posiedzenia komisji granicznej w Hadze, na których miało dojść do jej delimitacji i sporadycznie podejmują akcje zbrojne wobec sąsiada.

W Etiopii po obaleniu komunizmu wprowadzono od 1 sierpnia 1995 r. ustrój federalny, dzieląc kraj na dziewięć autonomicznych stanów, z których większość 
ma charakter etniczny (Amhara, Tigraj, Afar, Somali, Region Ludów Gambeli, Region Ludu Harari, Oromia, Region Narodów, Narodowości i Ludów Południa) (Łykowska 1999, s. 216). Granice wewnętrzne mają zatem w Etiopii range państwowych wewnątrzfederacyjnych. Federalizacja kraju nie rozwiązała konfliktu w Ogadenie (obecnie nazwanym Somali), gdzie od 1996 r. działa somalijska bojówka islamistyczna.

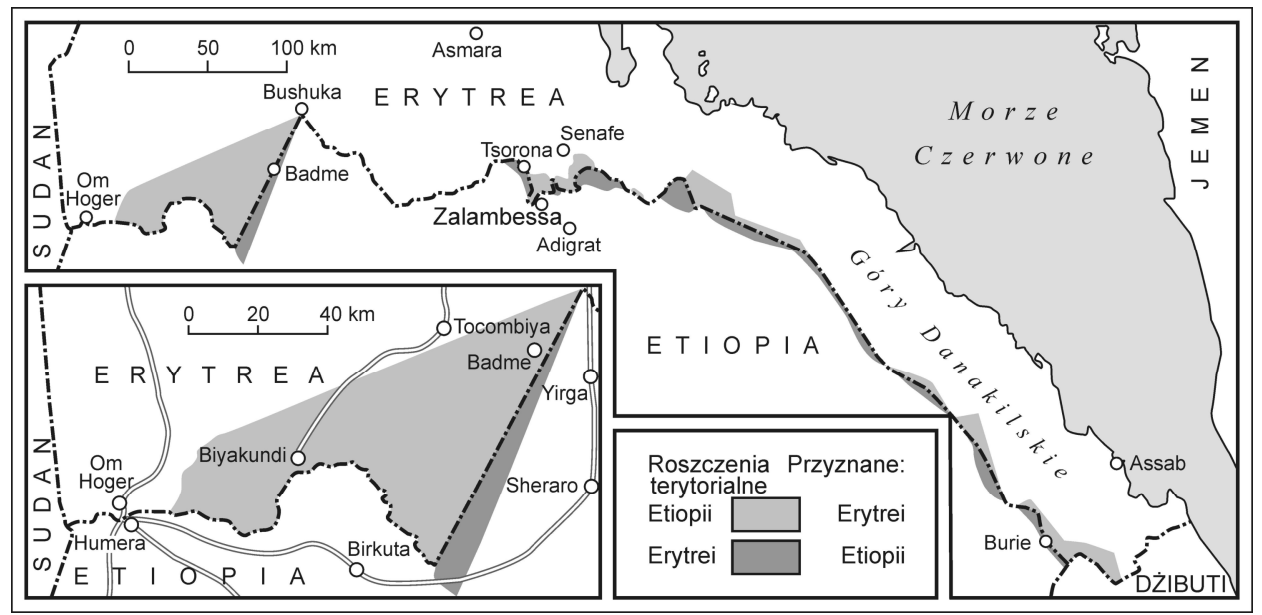

Ryc. 4. Spór graniczny etiopsko-erytrejski Źródło: opracowanie własne na podstawie:

Eritrean... (2015), Border war... (2015)

Nawet tak małe powierzchniowo państwo, jakim jest proklamowana 27 czerwca 1977 r. Republika Dżibuti, doświadczyło wojny domowej i podziału kraju na strefy kontrolowane przez oponentów - rządzące Ludowe Zgromadzenie na rzecz Postępu (RPP), grupujące głównie Issów (Somalijczyków) oraz opozycyjny Front Przywrócenia Jedności i Demokracji (FRUD) wspierany przez Afarów (Danakilów). W latach 1991-1994 Afarowie kontrolowali północ kraju, oblegając największe ośrodki miejskie Tadżurę i Obock (Boniface 2001, s. 121). Interwencja wojsk francuskich w 1992 r. nie uspokoiła sytuacji, trzykrotnie zerwano też rokowania pokojowe. Dopiero podjęta w czerwcu 1993 r. ofensywa wojsk rządowych doprowadziła do odzyskania kontroli nad północą Dżibuti i spowodowała masową ucieczkę Afarów do Etiopii (Domański 1999, s. 358). Pokój zawarto 26 grudnia 1994 r., ale sporadyczne starcia trwały nadal, aż do zawarcia ostatecznego porozumienia opozycji z rządem 12 maja 2001 r. (Polity IV... 2010, s. 2).

W 2008 r. doszło też do krótkotrwałej wojny granicznej na przylądku Ras Doumeira pomiędzy Dżibuti i Erytreą, której wojska okupowały, w okresie 
10-13 czerwca, kilka wiosek na północy Dżibuti (Mesfin 2008) (ryc. 5). Wsparcie wojsk francuskich pozwoliło wyprzeć agresora (Arab League... 2008). Na początku czerwca 2010 r. oba kraje zdecydowały się, za radą Unii Afrykańskiej, na przekazanie sporu pod mediację Kataru.

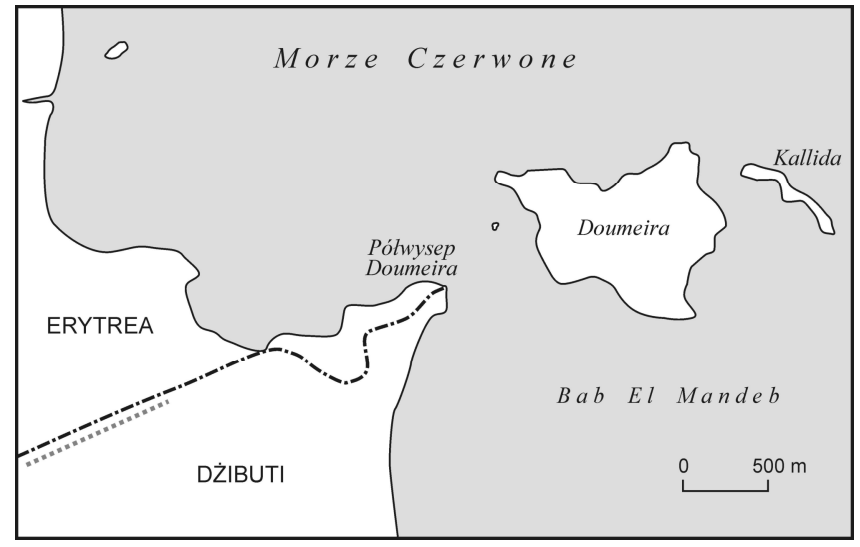

Ryc. 5. Rejon sporny pomiędzy Erytreą i Dżibuti na Przylądku Doumeira Źródło: Djiboutian... (2015)

Jednym z najstarszych konfliktów afrykańskich, bo trwającym od ogłoszenia 1 stycznia 1956 r. niepodległości przez anglo-egipski Sudan, jest wojna domowa w tym kraju (Sobczyński 2012 s. 258). Na początku niepodległości Sudanu dominującą grupą etniczną byli Arabowie, zamieszkujący północną, środkową i wschodnią część kraju, jednak z upływem czasu, z powodów demograficznych, przewagę liczbową uzyskała ludność czarna z południa i zachodu kraju, stanowiąca 52\% populacji, podczas gdy udział Arabów spadł do 39\% (Kurcz 2008, s. 135). Na zachodzie Sudanu zamieszkuje lud Fur, ludność czarna, ale wyznająca islam i mówiąca po arabsku. Większość czarnych na południu to animiści (12\%) lub chrześcijanie różnych kościołów (17\%). Ta diametralna zmiana struktur etnicznych miała przełożenie na sytuację polityczną i była powodem licznych konfliktów oraz dążeń separatystycznych.

Konflikt w Sudanie zakończył się drugą, jak dotąd w Afryce, udaną i uznaną międzynarodowo secesją prowincji (ryc. 6). Obecnie wydziela się w dawnym Sudanie trzy czynne konflikty. Jest to konflikt wewnętrzny pomiędzy rządem Sudanu a ludnością w prowincjach Kordofan Południowy i Nil Błękitny oraz konflikt wewnętrzny w Sudanie Południowym pomiędzy rządem a plemionami przeciwnymi niedawnej secesji Południa. Jest też nowy konflikt międzynarodowy pomiędzy oboma państwami sudańskimi o granicę (co przypomina sytuację secesji Erytrei z Etiopii i natychmiastową wojnę o granicę pomiędzy nimi) (Sobczyński 2012, s. 259). 


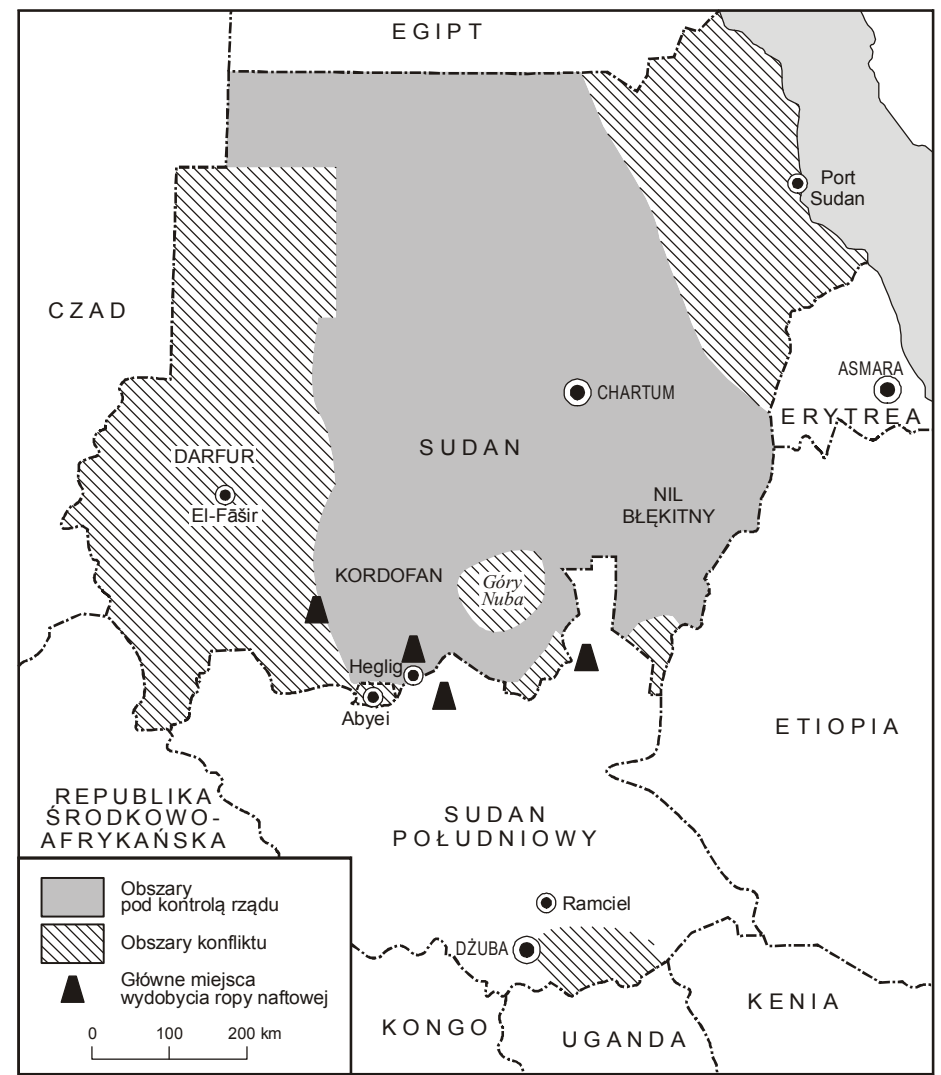

Ryc. 6. Secesja Sudanu Południowego oraz wojny domowe w Sudanie Źródło: M. Sobczyński (2012, s. 264)

U zarania konfliktów sudańskich był konflikt zbrojny Północy z Południem, który wiązał się z wydarzeniami jeszcze sprzed uzyskania niepodległości. Brytyjsko-egipskie panowanie nad Sudanem od 1899 r. w praktyce dzieliło kraj na dwie części, arabską Północ, administrowaną głównie przez Egipcjan, i Południe stanowiące niemal całkowitą domenę Brytyjczyków, którzy sprzyjali afrykanizacji regionu. Dopiero w 1946 r., pod naciskiem arabskim, na tzw. konferencji administracyjnej Brytyjczycy zgodzili się na zjednoczenie obu części Sudanu. W 1953 r. zawarto traktat o wycofaniu wojsk brytyjskich i egipskich z Sudanu, a po trzech latach sudańskie Zgromadzenie Narodowe miało zdecydować o dalszych losach kraju (Calvocoressi 2002, s. 684-690). Wybory wygrały siły proegipskie z Partii Narodowo-Unionistycznej, co wywołało gwałtowne demonstracje zwolenników suwerenności. Zastępując administrację egipsko-brytyjską, nowe władze na 800 stanowisk przedstawicielom Południa kraju przyznali jedynie cztery. 
Południe, które nie uczestniczyło w rokowaniach z 1953 r., zaproponowało ustrój federacyjny, ale Północ odrzuciła ten model i przeforsowała system unitarny. Jeszcze przed formalnym proklamowaniem niepodległości Republiki Sudanu, bo 18 sierpnia 1955 r., w południowej prowincji Ekwatoria wybuchło powstanie zbrojne, wywołane przez bunt Korpusu Równikowego w okręgu Torit, szybko jednak zakończone. Po puczu wojskowym, nowe władze Sudanu prowadziły forsowną arabizację $\mathrm{i}$ islamizację kraju, co spotkało się z oporem Południa i wybuchem w $1963 \mathrm{r}$. kolejnego powstania, tym razem bardziej zorganizowanego, gdyż kierowanego przez organizację Anya Nya (Boniface 2001, s. 134-135).

Powrót do rządów demokratycznych w Sudanie nastąpił po masowych demonstracjach w 1964 r., ale próba zawarcia pokoju z Południem nie przyniosła rezultatu. W 1969 r. wojsko dokonało kolejnego przewrotu i Sudan na krótko stał się sojusznikiem ZSRR, ale po nieudanym przewrocie komunistycznym w 1971 r. nawiązał relacje z Zachodem. Udało się wówczas zakończyć pierwszą fazę konfliktu na Południu, podpisaniem w Addis Abebie 27 marca 1972 r. porozumienia pokojowego z Ruchem Wyzwolenia Południowego Sudanu (SSLM). Południe otrzymało autonomię, własny rząd i parlament, przedstawicieli w parlamencie w Chartumie, język angielski stał się tam urzędowym, a bojownicy Anya Nya mieli zasilić armię Sudanu. Na Południu miało być przeprowadzone referendum (Stankiewicz 2005, s. 101). W ten sposób na prawie 10 latach pojawiła się granica państwowa wewnątrz Sudanu, oddzielająca autonomiczne Południe od reszty kraju, choć ustrój pozostał nadal unitarny.

Niestety, realizacja porozumienia nie przebiegała zgodnie z zapisem, powstańcy nie rozwiązali organizacji wojskowej, tylko przekształcili ją w Anya Nya II, a w 1979 r. na Południu odkryto bogate złoża ropy naftowej, co skomplikowało sytuację. W 1983 r. władze Sudanu wprowadziły szariat, co na Południu wywołało 16 maja 1983 r. bunt garnizonu w Bor. Powołano Ludowy Ruch Wyzwolenia Sudanu (SPLM), a jego zbrojnym ramieniem była Ludowa Armia Wyzwolenia Sudanu (SPLA) pod dowództwem Johna Garanga (Ząbek 1999, s. 143). Rząd Sudanu 5 czerwca 1983 r. złamał porozumienie z Addis Abeby i podzielił Południe na trzy odrębne regiony, a następnie 29 kwietnia $1984 \mathrm{r}$. wprowadził na Południu stan wyjątkowy i sądy szariackie (Sobczyński 2012, s. 261). W 1985 r. w Sudanie dokonano kolejnego puczu, a nowe władze przywróciły demokrację. Na spotkaniu w Addis Abebie SPLM i sudańska opozycyjna partia Umma 24 marca 1986 r. podpisały deklarację Koak Dam, wzywającą do rozejmu, zniesienia szariatu i zwołania narodowej konferencji konstytucyjnej. Po wyborach w 1986 r. premier Sudanu spotkał się nawet z Garangiem, ale zestrzelenie w sierpniu 1986 r. przez SPLM pasażerskiego samolotu linii sudańskich doprowadziło do zerwania procesu pokojowego. 
W czerwcu 1989 r. armia sudańska dokonała kolejnego puczu i na czele państwa stanął brygadier Omar Hassan al-Baszir, rządzący Sudanem do dziś jako bezwzględny dyktator. Parlament rozwiązano, wprowadzono stan wyjątkowy w całym kraju, zawieszono konstytucję i rozwiązano partie polityczne. Ideologią władzy stał się fundamentalizm islamski, a wojnę z Południem określono jako dżihad. Po 2000 r. jedność polityczna islamistów i dyktatora zaczęła słabnąć, co otworzyło nowe szanse na uregulowanie sytuacji wewnętrznej kraju. Od sierpnia 1989 r. reżim podjął rokowania z Południem, najpierw w Addis Abebie, a w grudniu w Nairobi, przy mediacji byłego prezydenta USA Jimmy Cartera, które nie przyniosły rezultatu, podobnie jak prowadzone w latach 19921993 rokowania w Abudży przy mediacji Nigerii (Wiatrowski 1999, s. 157). W 1994 r. do mediacji włączyły się afrykańskie instytucje międzypaństwowe. Od września 2001 r. w rokowaniach uczestniczył specjalny wysłannik prezydenta Georga Busha - John Danforth. Z jego pomocą, 19 stycznia 2002 r. obie strony uzgodniły w szwajcarskim Burgenstock sześciomiesięczny odnawialny rozejm w dotkniętych głodem Górach Nuba.

Kluczowym momentem było podpisanie 26 lipca 2002 r., w kenijskim Machakos, porozumienia uznającego prawo Południa do określenia przyszłego statusu politycznego na drodze referendum i prawa Północy do zachowania u siebie szariatu. Od tego momentu rokowania pokojowe nabrały tempa i 15 października 2002 r. obie strony zawarły rozejm w wojnie domowej na czas dalszych rokowań pokojowych. Układ pokojowy podpisano 9 stycznia $2005 \mathrm{r}$. w Nairobi. Zakończył się tym samym konflikt wewnętrzny w Sudanie trwający dokładnie pół wieku. Pochłonął $2 \mathrm{mln}$ istnień ludzkich i spowodował wygnanie $4 \mathrm{mln}$. Ustalono świecki charakter Południa, przy zachowaniu szariatu na Północy, równy podział dochodów ze złóż ropy naftowej leżących na Południu, samorządność Południa z prawem do własnej armii i proporcjonalnym udziale we władzach centralnych (w tym funkcji wiceprezydenta) oraz prawa do referendum niepodległościowego po sześciu latach od wejścia życie układu (czyli w 2011 r.) (Sobczyński 2012, s. 261-262).

Sukces polityczny czarnej ludności Południa i prawo do decydowania w referendum o swoim losie były wzorcem dla innych dyskryminowanych grup społecznych Sudanu, który spowodował rozszerzenie wojny domowej w tym państwie na inne regiony.

Wojna domowa rządu z mieszkańcami zachodniej prowincji Darfur, wybuchła w 2003 r. Stronami konfliktu byli arabscy wojownicy Dżandżawidzi, jawnie wspierani przez rząd, których celem było odebranie czarnej ludności regionu bardziej urodzajnych ziem i zepchnięcie ich na pustynię lub poza granice Sudanu. Walkę z Dżandżawidami toczył Ruch Sprawiedliwości i Równości (JEM) (Thu 2004, s. 20). Starcia w 2004 r. przybrały takie rozmiary, że świat 
uznał je za czystkę etniczną i ludobójstwo, o co w 2009 r. oskarżono osobiście prezydenta al-Baszira przed Międzynarodowym Trybunałem Karnym (jako pierwszą urzędującą głowę państwa).

Rokowania pokojowe zainicjowała RB ONZ w 2005 r., która powołała misję pokojową UNMIS. W 2006 r. JEM wraz z Ruchem Wyzwolenia Sudanu (SLM) stworzył nową organizację powstańczą Alians Sił Rewolucyjnych Zachodniego Sudanu (ARSWS). Wzorem Sudanu Południowego powstańcy żądali autonomii i prawa do secesji z Sudanu, choć poza rasą nie wyróżniała ich ani religia, ani język. Powstańcy zaatakowali pola naftowe Dafra w Kordofanie, a w maju 2008 r. dotarli aż pod Chartum i Omdurman. Początkowe masakry ludności cywilnej Darfuru zamieniły się w zagrożenie dla centrum administracyjnego Sudanu, a nacisk opinii międzynarodowej oskarżającej kraj o ludobójstwo zniechęcił władze do kontynuowania konfliktu. Kolejne działania ONZ w 2007 r. zaowocowały utworzeniem, wspólnie z Unią Afrykańską, sił pokojowych (UNAMID), które 31 grudnia 2007 r. przejęły dowództwo w Darfurze (Sudan's spreading...III... 2014).

Zatem powstała w Sudanie kolejna granica międzynarodowa oddzielająca prowincję Darfur od reszty Sudanu. Pomimo zawarcia 23 lutego 2010 r. w Kairze rozejmu, lokalnie walki toczyły się jeszcze do 25 grudnia 2011 r. Układ pokojowy zawarto w stolicy Kataru Dausze, 14 lipca 2011 r., pomiędzy rządem Sudanu a nowo powstałą w maju 2010 r. organizacją powstańców - Ruchem Wyzwolenia i Sprawiedliwości (LJM). Władzę w Darfurze 6 lutego 2012 r. przejął Regionalny Zarząd Darfuru, z siedzibą w Al-Fashir, co oznacza pełną autonomię regionu. Granica Darfuru z resztą terytorium Sudanu zyskała rangę granicy wewnątrzfederacyjnej.

Ostatecznie losy Sudanu rozstrzygnęły się 9-15 stycznia 2011 r. podczas referendum na Południu, w którym 98,93\% głosujących wybrało niepodległość regionu, przy bardzo wysokiej frekwencji, jak na uwarunkowania fizjograficzno-komunikacyjne kraju. Niepodległość Republiki Sudanu Południowego, o ustroju federacyjnym, proklamowano 9 lipca 2011 r. w stolicy Dżubie, a pierwszym państwem, które ją uznało, był Sudan. Zaakceptowano też członkostwo Sudanu Południowego w ONZ (14 lipca 2011 r.) oraz w Unii Afrykańskiej (28 lipca tego roku). Sudan Południowy ma powierzchnię 619,7 tys. $\mathrm{km}^{2}$ i zamieszkuje go 10,6 mln ludności. W lutym 2011 r. ogłoszono plan budowy nowej stolicy Ramciel, nieco na północ od obecnej. Granica Sudanu z Sudanem Południowym stała się kolejną w Afryce nową granicą międzynarodową, a wkrótce także zarzewiem wojny. Sudan do 2011 r. był największym państwem afrykańskim, o powierzchni przekraczającej $2,5 \mathrm{mln} \mathrm{km}^{2}$. Obecnie, po secesji Sudanu Południowego, jest trzecim państwem w Afryce, liczy bowiem 1886 tys. km² i zaludnia go 31 mln osób (Sobczyński 2012, s. 258). 
Podział Sudanu nie zakończył jednak konfliktów, wprost przeciwnie, pojawiły się kolejne, które aktualnie trwają zarówno w formie wojen domowych w Sudanie i Sudanie Południowym, jak i konfliktu międzynarodowego pomiędzy oboma państwami.

Na wschodzie Sudanu od lat toczyły się walki z powstałym w lutym 2004 r. Kongresem Beja oraz Wolnymi Lwami Raszida, bazującymi na plemionach Beja i Raszida. Obie grupy współpracowały też z JEM z Darfuru. W styczniu 2005 r. Beja zaatakowali główny port kraju Port Sudan, wspierani przez Erytreę. Bojownicy frontu wschodniego walczyli o autonomię regionu, a także zapowiadali wyzwolenie Trójkąta Hala'ib, terytorium spornego pomiędzy Egiptem i Sudanem nad Morzem Czerwonym, którym od 1990 r. administruje Egipt. Zasadniczym powodem konfliktu są bogate złoża ropy naftowej na wschodzie Sudanu. Udało się doprowadzić 19 czerwca 2006 r. do podpisania porozumienia o zasadach wzajemnych relacji rządu i plemion Wschodu. Układ pokojowy zawarto 14 października 2006 r. w stolicy Erytrei Asmarze. Uzgodniono zakres władzy centralnej przekazywanej na poziom lokalny trzech wschodnich prowincji, Morze Czerwone, Kassala i Al-Qadarif, i powołano nowy organ władzy Wschodniosudański Państwowy Komitet Koordynacyjny. Po kilku latach pokoju rezultaty tych uzgodnień okazały się niezadowalające dla ludności Wschodu i 8 stycznia 2011 r. powołano wspólną organizację Wschodu i Darfuru (z połączenia JEM i organizacji wschodnich) - Federalny Alians Sudanu Wschodniego (FAES), dla wspólnego zwalczania reżimu al-Baszira. Uzgodnienia wprowadziły kolejną państwową granicę w Sudanie, tym razem wewnątrzfederacyjną, oddzielającą unitarne prowincje centralne od autonomicznego Wschodu.

Kolejny etap wojny domowej dotyczył dwóch południowych (w nowym kształcie terytorialnym Sudanu) prowincji: Kordofanu Południowego i Nilu Błękitnego. Kordofan Południowy jest dużą prowincją o powierzchni 158 tys. km², ale słabo zaludnioną (nieco ponad $1 \mathrm{mln}$ mieszkańców). Początkiem konfliktu były spory w 2009 r. pomiędzy nomadycznymi plemionami. Jest prawdopodobne, że były celowo wywołane przez rząd, aby zdestabilizować cały region i nie dopuścić do secesji Południa. Już pierwsze incydenty wywołały masowe migracje. W 2010 r. walki się nasiliły, a po stronie antyrządowej pojawiła się organizacja Sudański Ludowy Ruch Wyzwolenia - Północ (SPLM-N) nawiązujący nazwą do analogicznej organizacji walczącej o niepodległość Południa. Powstańcy objęli swą aktywnością prowincje Kordofan Południowy i Nil Błękity, a ich celem było oderwanie prowincji od Sudanu i zniesienie szariatu. Akcje zbrojne nasiliły się po secesji Sudanu Południowego. Powstańcy z obu prowincji współpracowali z JEM z Darfuru i wspólnie 19 lipca 2011 r. zaatakowali posterunek armii sudańskiej w Pisea w Kordofanie. Spowodowało to ucieczkę ze swoich siedzib ok. 400 tys. mieszkańców Gór Nuba. Walki w pro- 
wincji Nil Błękitny wybuchły w sierpniu-wrześniu 2011 r. Na przełomie września i października SPLM-N utworzyła w prowincji swój rząd w Kurmuku, który kontrolował dużą część regionu. Rząd Sudanu uznał prawa mieszkańców do decydowania o przyszłym statusie prowincji, ale lokalny gubernator Ahmed Haroun przystąpił do eksterminacji ludności miejscowej, za co stał się kolejnym sudańskim politykiem oskarżonym przez MTS o zbrodnię ludobójstwa.

Jedenastego listopada 2011 r. ukonstytuowała się w Sudanie nowa siła polityczna, opozycyjna wobec obecnej dyktatury, Sudański Front Rewolucyjny (SRF), który zawarł w Kampali 5 stycznia 2013 r. układ z pozostałymi siłami sudańskiej opozycji zwany „Kartą Nowego Przełomu”, przewidujący zakończenie wewnętrznych konfliktów, przywrócenie demokracji i w jej ramach zneutralizowania dążeń separatystycznych poprzez federalizację ustroju (Sudan's spreading...I... 2013, Sudan's spreading...II... 2013).

Analogicznie jak w przypadku Etiopii i Erytrei, również pomiędzy oboma państwami sudańskimi wspólna granica, mająca już charakter międzynarodowy, stała się przedmiotem sporu, który przerodził się w wojnę (ryc. 7). Zapowiedzią tego konfliktu były trudności ustalenia wspólnej granicy w okresie przygotowania do secesji Południa. Spór dotyczył dwóch regionów pogranicza Abyei i Heglig, w których wydobywa się ropę naftową. Nie mogąc się porozumieć co do przebiegu przyszłej granicy międzypaństwowej, obie strony zwróciły się w 2009 r. do Stałego Trybunału Arbitrażowego w Hadze, który miał podzielić terytorium pomiędzy plemiona Dinka (czarni) i Misseriya (Arabowie). Trybunał dokonał tego podziału na terytorium Abyei, ale nie zajął się leżącym bardziej na północ, należącym do Kordofanu miasteczkiem Heglig (Toboła 2012, s. 5). Dziesiątego kwietnia 2012 r. wojska Sudanu Południowego zajęly pola naftowe Heglig i okupowały je przez 10 dni, do czasu interwencji armii Sudanu. Rząd południowosudański nie uznaje jednak jurysdykcji sudańskiej i skierował sprawę ponownie do Trybunału Arbitrażowego.

Sporny obszar Abyei obejmuje 10,5 tys. $\mathrm{km}^{2}$ powierzchni i zamieszkany jest przez ok. 20 tys. mieszkańców. Już w umowie z Addis Abeby z 1972 r., kiedy po raz pierwszy Południe otrzymało autonomię, przewidziano referendum w Abyei na temat jego przynależności. Referendum się nie odbyło, a Dinkowie wsparli organizację powstańczą Anya Nya II, podczas gdy Masseriya popierali rząd w Chartumie. W dalszym toku wojny Dinkowie wsparli SPLA, a ich oponenci stworzyli milicję Murahleen, atakującą z gór nizinne osiedla Czarnych, porywając ich w niewolę. Podpisane rozejmy pomiędzy Północą a Południem nie rozwiązały sporu. Układ z Machakos z 2002 r. mówił o autonomii Sudanu Południowego w granicach z 1956 r., co wykluczało Abyei, Nil Błękitny i Góry Nuba. 


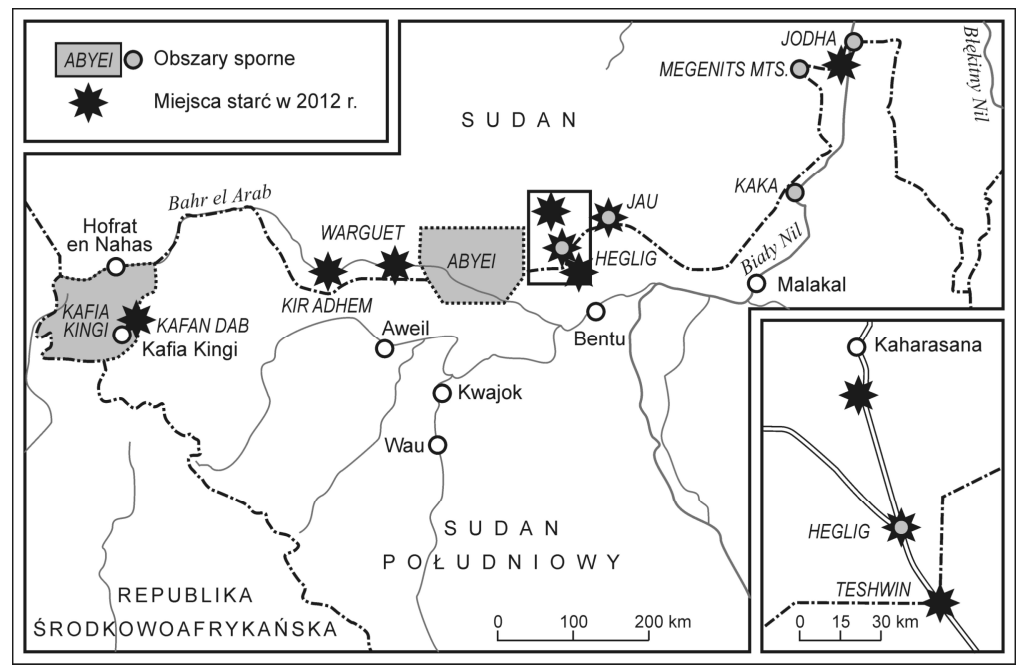

Ryc. 7. Wojna graniczna Sudanu z Sudanem Południowym Źródło: opracowanie własne na podstawie: Sudan and... (2012)

Południe cały czas negocjowało kształt swego terytorium, mając nadzieję, że po referendum niepodległościowym sprawa się rozwiąże, ale rząd tak manewrował, aby nie dopuścić do referendum na spornym obszarze. Przy mediacji Stanów Zjednoczonych ustalono dodatkowy protokół w kwestii Abyei, który nadał terytorium specjalny status i odrębną administrację (ryc. 8). Mieszkańcy Abyei mieli do czasu referendum być jednocześnie obywatelami Północy i Południa. Granice miała wyznaczyć Komisja Graniczna Abyei. Komisja przeprowadziła granicę $84 \mathrm{~km}$ na północ od miasta Abyei i 14 maja 2005 r. przedstawiła swój raport, ale rząd go odrzucił, motywując to wykorzystaniem przez ekspertów map z $1905 \mathrm{r}$. W październiku $2007 \mathrm{r}$. doszło do starć zbrojnych w spornym regionie armii rządowej z SPLA, co zostało uznane za zagrożenie dla pokoju w Sudanie. W 2008 r. trwały starcia zarówno pomiędzy SPLA i armią Sudanu, jak i SPLA oraz milicją ludu Masseriya. Masseriya odrzucali ustalenia Komisji Granicznej jako ich krzywdzące. Murahleen, milicja tego plemienia nie podlegała bezpośrednio Chartumowi, ale była przez niego manipulowana. W marcu 2008 r. Sudan zwiększył swoje siły w Abyei o 200 żołnierzy. Walki w maju 2008 r. spowodowały ucieczkę 25 tys. osób, a miasto zostało zrujnowane.

Po dalszych starciach, w czerwcu 2008 r., przywódcy obu stron zgodzili się oddać spór do międzynarodowego arbitrażu. Trybunał Międzynarodowy 22 lipca 2009 r. zmienił granice, znacząco zmniejszając obszar Abyei. Najbogatsze pola naftowe znalazły się na Północy, tylko jedno pozostało w Abyei. Także ziemie plemienne Masseriya zostały wyłączone, co dawało nadzieję, że w nowym kształcie obszar Abyei zagłosuje za Południem. Obie strony zgodziły się na 
ustanowienie specjalnego zarządu strefy pod kontrolą Stanów Zjednoczonych, UE i ONZ. Pomimo zbliżającego się terminu referendum, do grudnia 2010 r. nie ustalono granic strefy; 21 maja 2011 r. armia Sudanu zajęla strefę Abyei, po trzydniowych walkach z siłami Południa. Sudan Południowy ogłosił, że jest w stanie wojny z Sudanem i zwrócił się do ONZ z prośbą o interwencję. Akcja ta zniwelowała szansę na referendum w Abyei, zdymisjonowano gubernatora regionu i Północ mianowała swojego. Interwencja ONZ sprawiła, że 20 czerwca 2011 r. zawarto rozejm, a do Abyei 27 czerwca przybyły siły rozjemcze UNISFA.

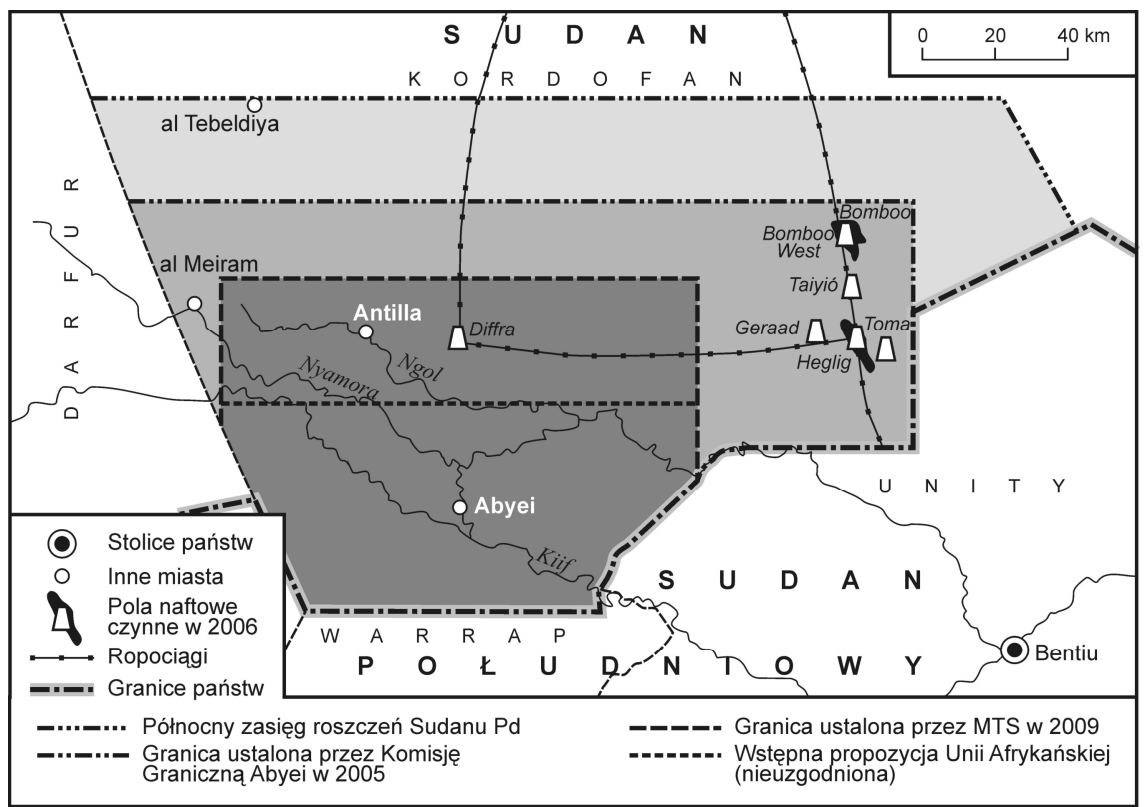

Ryc. 8. Spór terytorialny Sudanu i Sudanu Południowego o roponośny region Abyei Źródło: opracowanie własne na podstawie: I. Amrani (2012)

Sudan jest też w sporze granicznym z Egiptem o tzw. Trójkąt Hala'ib, o powierzchni 20,6 tys. $\mathrm{km}^{2}$, położony na granicy obu państw, na Pustyni Arabskiej nad Morzem Czerwonym, i styczny z nim obszar Bir Tawil, o powierzchni 2 tys. $\mathrm{km}^{2}$. Podczas dominacji brytyjskiej w $1899 \mathrm{r}$. granicę wyznaczono po 22 równoleżniku. Po uzyskaniu niepodległości przez Sudan w 1956 r., Egipt przekazał mu część spornego trójkąta z uwagi na interes plemienia Biszari (Ząbek 1999, s. 134). W 1992 r. Egipt nie zgodził się z sudańską koncesją na poszukiwanie ropy naftowej na spornym obszarze, udzieloną Kanadzie, i wprowadził do trójkąta swoje wojska. W 2000 r. Sudan wycofał wojska ze spornej strefy, choć nie zrezygnował z roszczeń, a Egipt nadal je tam utrzymuje. 
Obszar Bir Tawil od 1902 r. jest pod administrację egipską. Egipt jest gotowy przekazać ten obszar Sudanowi w zamian za jego rezygnację z roszczeń do Trójkąta Hala'ib. Słaba kontrola egipska nad Bir Tawil pozwoliła obywatelowi amerykańskiemu proklamować tam, 16 czerwca 2014 r., Królestwo Północnego Sudanu, gdyż chciał sprawić córce prezent w postaci tytułu księżniczki (American $\mathrm{dad}_{\text {... 2014). }}$.

Nowo utworzony Sudan Południowy stał się także sceną konfliktu wewnętrznego, bez wątpienia związanego z kwestią Abyei oraz inspirowanego przez rząd Sudanu. Początkowo walkę z rządem prowadziły Amia Wyzwolenia Sudanu Południowego (SSLA) oraz Armia Demokratycznego Ruchu Sudanu Południowego (SSDA) (Toboła 2012, s. 9).

Ruch Wyzwolenia Sudanu Południowego, powstały w listopadzie 1999 r., był organizacją ludu Nuerów i działał w prowincji Górny Nil. Celem było rozbicie jednolitego frontu Zachodnich Nuerów w prowincji Unity (Zachodni Górny Nil) walczących z centralnym rządem Sudanu. SSLM zawarł z rządem w Chartumie układ pokojowy 21 kwietnia 1997 r., stając się milicją prorządową, która atakowała pola naftowe kontrolowane przez SPLA w Bahr el-Gazal, aby wymusić powrót uchodźców Nuerów na te tereny. Po uzyskaniu niepodległości przez Sudan Południowy aktywność grupy osłabła, ale nadal była ona używana przez Sudan do siania niepokoju. Organizacja ta przypomniała o sobie 11 kwietnia 2011 r., ogłaszając Deklarację z Mayom, wzywającą rząd Sudanu Południowego do wyzwolenia się spod kontroli „stołecznej mafii” i przekształcenia w rząd jedności narodowej. Rząd Sudanu Południowego zaoferował 26 kwietnia 2013 r. amnestię dla tych bojowników SPLA, którzy złożą broń, wracając z Sudanu. Skorzystało z niej ok. 3 tys. Nuerów, ułaskawieni mogli wstąpić do armii Sudanu Południowego.

W stanie wojny z rządem Sudanu Południowego jest Demokratyczny Ruch Sudanu Południowego założony w 2010 r. przez przywódcę Ludowej Armii Wyzwolenia Sudanu - George Athora, po jego porażce w wyborach na gubernatora prowincji Jonglei, na wschodzie kraju. Organizacja reprezentuje plemię Murle, które od lat pozostawało w sporze o stada bydła i ziemię z Nuerami, co w 2011 r. doprowadziło do walk międzyplemiennych. Athor został zabity w Ekwatorii 19 grudnia 2011 r. przez wojska Sudanu Południowego, ale walki międzyplemienne trwały jeszcze do końca roku.

Szerszy niż lokalny wymiar wojna domowa w Sudanie Południowym przybrała po zdymisjonowaniu, 23 lipca 2013 r. przez prezydenta Salvę Kiira (z ludu Dinków), jego zastępcy Rieka Machara (z ludu Nuerów), kiedy ten drugi zapowiedział kandydowanie w wyborach prezydenckich przewidzianych na 2015 r. (The military... 2014, s. 2). Próba rozbrojenia Nuerów, stacjonujących w stolicy kraju Dżubie, doprowadziła 15 grudnia 2013 r. do wybuchu walk; 
17 grudnia Nuerowie zostali wyparci ze stolicy, ale opanowali stany Jonglei i Unity. Miasta Bor, Bentiu, Tar Dżat, Malakal w ciągu kilku miesięcy wielokrotnie przechodziły z rąk do rąk (ryc. 9). Do wojny 19 grudnia dołączyła po stronie rebeliantów Biała Armia Nuerów (NWA), która zaatakowała pokojowe siły ONZ w Akobo, ostrzelano też amerykański samolot wojskowy (The military... 2014, s. 6). Dzięki mediacji instytucji afrykańskich 23 stycznia 2014 r. zawarto rozejm, który nie był przestrzegany i walki wybuchły z nową siłą.

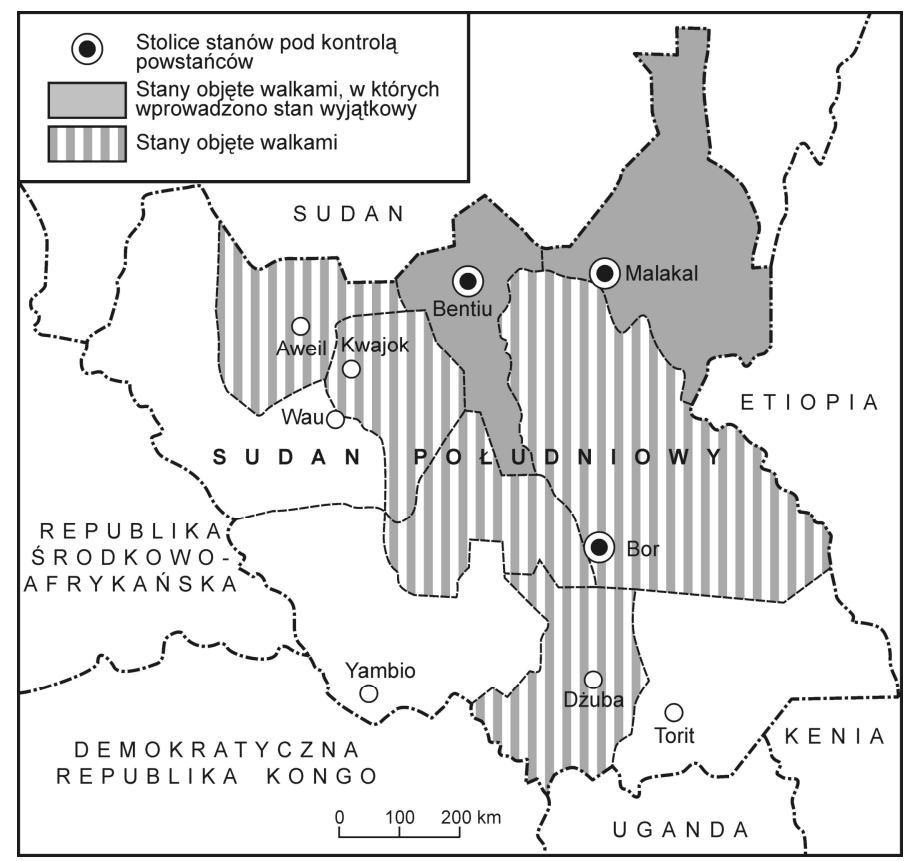

Ryc. 9. Wojna domowa w Sudanie Południowym 2013-2015

Źródło: opracowanie własne na podstawie: South Sudan ... (2014, s. 37)

Obie strony konfliktu wykazały się okrucieństwem wobec cywilów z przeciwnych plemion. Naciski opinii międzynarodowej, ONZ, Unii Afrykańskiej i Europejskiej oraz Stanów Zjednoczonych, które wycofały swoich ekspertów z Sudanu Południowego, skłoniły strony konfliktu do rokowań pokojowych zwieńczonych układem z Addis Abeby 9 maja 2014 r. Uzgodniono powołanie rządu jedności narodowej, opracowanie nowej konstytucji Sudanu Południowego i ogłoszono wybory na 12 maja 2015 r. ONZ ponownie wysłał misję pokojową UNMISS i utworzył komisję do zbadania zbrodni wojennych (South Sudan... 2014, s. 28). W maju 2015 r. prezydent Sudanu Południowego odwołał zapowiedziane wybory, przesuwając je z powodu niestabilnej sytuacji w kraju na 2017 r. Podpisanie 26 sierpnia 2015 r. przez prezydenta Sylvę Kiira układu 
pokojowego formalnie kończy wewnętrzny konflikt w Sudanie Południowym. W ciągu 90 dni ma powstać rząd jedności narodowej, który przez 30 miesięcy ma sprawować władzę. Na stanowisko wiceprezydenta powróci Riek Machara. Władza $\mathrm{w}$ terenie będzie podzielona wedle stanu posiadania $\mathrm{w}$ chwili zawarcia rozejmu, a stolica Dżuba będzie zdemilitaryzowana. W ciągu 45 dni Sudan Południowy opuszczą obce wojska (Czarnecki 2015, s. 8).

\subsection{Afryka Poludniowa}

W okresie istnienia komunizmu w kilku państwach afrykańskich, głównie w koloniach portugalskich, ruchy narodowo-wyzwoleńcze zostały w części zdominowane przez ideologię komunistyczną i wspierane były militarnie przez ZSRR i Kubę. Portugalia zrezygnowała z posiadania kolonii po „rewolucji goździków” w 1974 r. Walkę o władzę w największych z nich, Angoli i Mozambiku, stoczyły ze sobą wyzwoleńcze organizacje komunistyczne i prozachodnie, a zwycięsko z nich wyszyły te pierwsze, przekształcając swoje państwa w centra afrykańskiego komunizmu. Przegrane siły prozachodnie nie złożyły jednak broni i doszło do faktycznego podziału tych państw na strefy kontrolowane przez komunistyczne rządy i obszary pod kontrolą sił prozachodnich, na tyle znaczne, że organizowano na nich administrację państwową konkurencyjną wobec rządowej.

W proklamowanej 11 listopada 1975 r. Ludowej Republice Angoli, część północną kraju, zamieszkaną przez lud Bakongo, jeszcze w okresie kolonialnym kontrolował Narodowy Front Wyzwolenia Angoli (FNLA), a całą część wschodnią i południową Narodowy Związek na rzecz Całkowitego Wyzwolenia Angoli (UNITA), związany z ludem Owimbundu. W najważniejszej gospodarczo, nadmorskiej, zachodniej części Angoli dominował komunistyczny Ludowy Ruch Wyzwolenia Angoli (MPLA), w którego skład wchodziła ludność Mbundu (Malaquias 2000, s. 103). W eksklawie Kabinda sporą część jej terytorium kontrolował Front Wyzwolenia Enklawy Kabindy (FLEC), aktywny tam do dziś.

Losy wojny domowej w Angoli w latach 1975-1992 r. cechowały się dużą zmiennością sytuacji politycznej i permanentną zmianą zasięgu kontrolowanych przez strony konfliktu terytoriów. Już w 1976 r. siły komunistyczne zajęły Kabindę i wyeliminowały z walki początkowo najsilniejsze ugrupowanie FNLA. $\mathrm{Na}$ placu boju pozostały zatem MPLA, wspierana militarnie przez wojska kubańskie i radzieckie, a gospodarczo i polityczne przez cały blok komunistyczny, oraz UNITA wspierana przez wojska RPA, a politycznie przez Zachód. Angola stała się gorącym poligonem ,zimnej wojny”. W drugiej połowie lat 70. XX w. siły komunistyczne opanowały niemal wszystkie ośrodki miejskie kraju i linie komunikacyjne, ale wkroczenie wojsk południowoafrykańskich, w latach 80., powiększyło zasięg przestrzenny obszarów pod kontrolą UNITA (ryc. 10). 


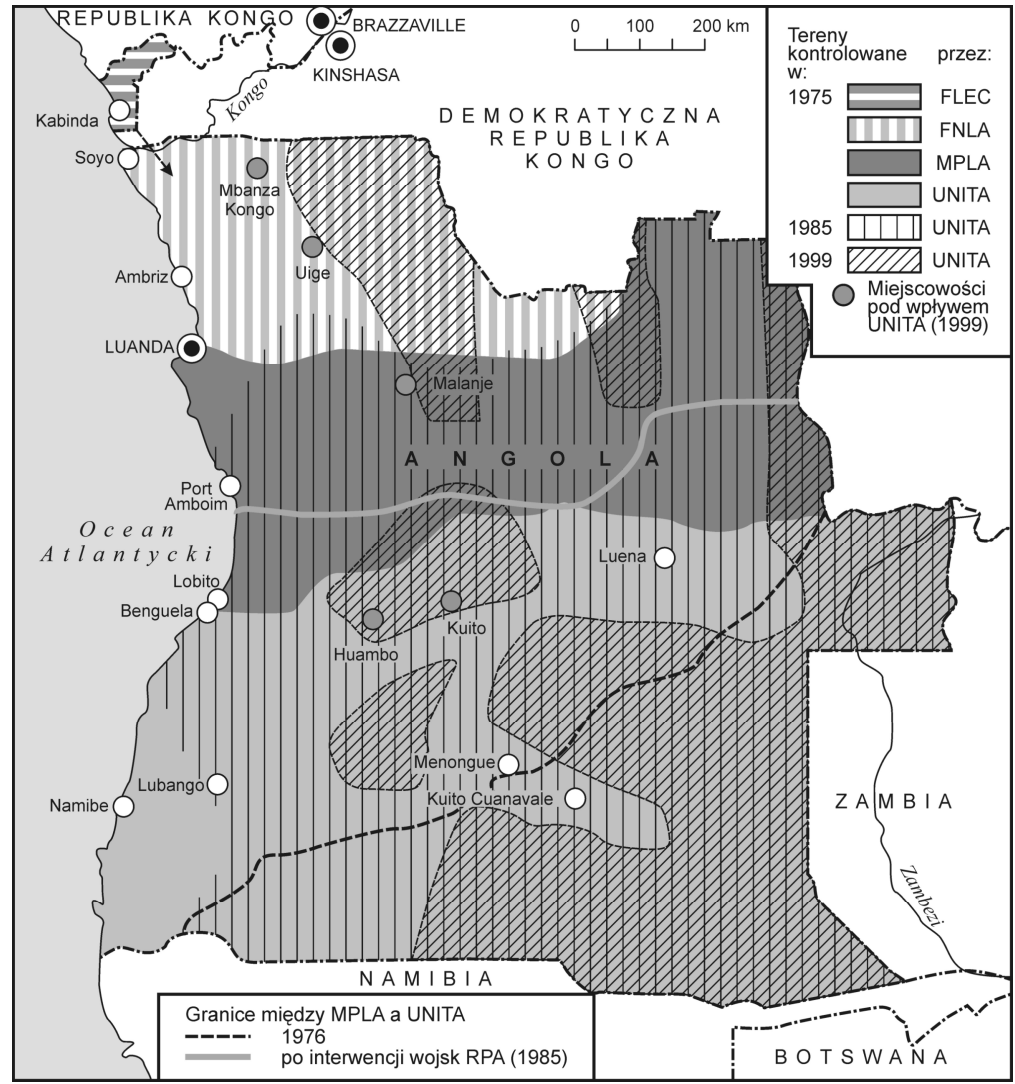

Ryc. 10. Wojna domowa w Angoli 1975-1992 Źródło: P. Boniface (2001, s. 147)

Po upadku komunizmu na świecie i wycofaniu wojsk interwencyjnych z Angoli udało się w 1992 r. doprowadzić do pokojowego rozwiązania konfliktu. W wyborach prezydenckich kandydat UNITA nieznacznie przegrał z przedstawicielem MPLA. Sporadyczne walki trwały jeszcze do 2002 r., ale kraj po wyborach został w praktyce zjednoczony, a jego władze odstąpiły od ideologii komunistycznej 25 sierpnia 1992 r., proklamując Republikę Angoli (Boniface 2001, s. 146-147).

W Mozambiku walkę narodowo-wyzwoleńczą z kolonistami portugalskimi prowadził lewicowy Front Wyzwolenia Mozambiku (FRELIMO), który przejął władzę po proklamacji niepodległości 25 czerwca 1975 r., przekształcając Mozambik w sojusznika ZSRR i centrum zwalczania apartheidu w RPA. Siły prozachodnie zawiązały w 1975 r. nową organizację Narodowy Ruch Oporu Mozambiku (RENAMO), która podjęła walkę zbrojną z komunizmem i objęła kontrolę nad dużą częścią kraju (Seibert 2003, s. 254) (ryc. 11). 


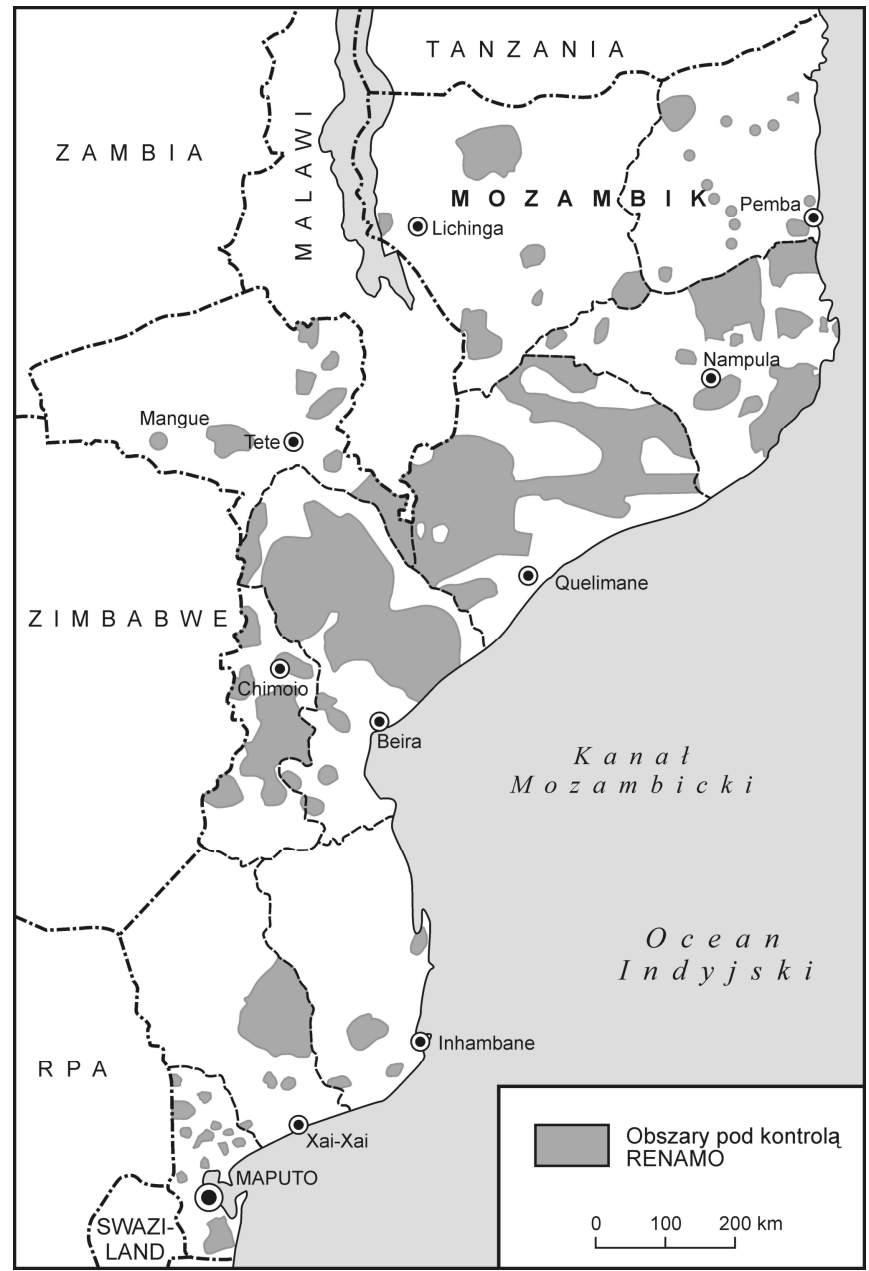

Ryc. 11. Obszary Mozambiku pod kontrolą prozachodniej opozycji RENAMO Źródło: opracowanie własne na podstawie: J. Hanlon, R. Waterhouse (1995, s. 6)

Po upadku komunizmu i apartheidu w $1990 \mathrm{r}$. obie strony podjęły rokowania pokojowe. W listopadzie 1990 r. zlikwidowano Ludową Republikę Mozambiku i przywrócono system demokratyczny. Układ pokojowy zawarty w Rzymie wszedł w życie 16 października 1992 r., a jego gwarantem były siły pokojowe ONZ. Wybory prezydenckie, podobnie jak w Angoli, wygrał były komunista (Hanlon, Waterhouse 1995, s. 1).

Okres podziału kraju przeżyły też, proklamowane jako niepodległe państwo 6 lipca 1975 r., Komory złożone z trzech większych wysp. Niezadowolone z podziału środków budżetowych dwie wyspy dokonały secesji: 3 sierpnia $1997 \mathrm{r}$. Państwo Anjouan (wyspa Ndzuwani) i 11 sierpnia Demokratyczna Republika 
Mohéli (na wyspie Mwali) (Warner 2010, s. 40). Po zmianie ustroju państwa na federacyjny udało się, 10 marca 2002 r., zjednoczyć wszystkie trzy wyspy archipelagu. Jednak na początku 2008 r. Ndzuwani ponownie dokonała secesji, kiedy rząd federalny i Unia Afrykańska uznały wybory na tej wyspie za sfałszowane. Wojska Komorów, wsparte przez Tanzanię i Senegal, dokonały 25 marca 2008 r. desantu na Ndzuwani i zakończyły rebelię. Zmiany charakteru granic w trakcie secesji oczywiście następowały (z wewnątrzfederacyjnych na państwowe), ale są to wyłącznie granice morskie. Na mocy referendum z 17 maja 2009 r. wyspy Ngazidja (Wielki Komor), Nzwani i Mwali utworzyły federacyjną Unię Komorów (Massey, Baker 2009, s. 5).

Krótki okres podziału wyspy dotknął także Republikę Madagaskaru, kiedy miała ona dwóch prezydentów. Po wyborach prezydenckich z 16 grudnia $2001 \mathrm{r}$. obaj kandydaci urzędujący, prezydent Didier Ratsiraka i kandydat na to stanowisko Marc Ravalomanana, uznali się zwycięzcami, tworząc dwa ośrodki władzy (Coleman 2002). Dotychczasowy prezydent uzyskał wsparcie ludności nadbrzeżnej prowincji Mahajanga i ogłosił w Toamasinie (prowincja Atsinanana) secesję północy wyspy. Nowo wybrany prezydent Ravalomanana, uzyskując poparcie Sądu Najwyższego (zdobył 46\% głosów wobec 40\% dla Ratsiraki), 22 lutego 2002 r. objął władzę w stolicy, a popierali go mieszkańcy centralnej części państwa (Africa south... 2004, s. 635). Dopiero w połowie czerwca 2002 r., dzięki naciskom Unii Afrykańskiej, przegrany prezydent Ratsiraka wyjechał do Francji i przywrócono jedność wyspy (Madagascar... 2003).

\subsection{Afryka Zachodnia}

W analogicznej sytuacji po wyborach prezydenckich na Wybrzeżu Kości Słoniowej, przeprowadzonych po śmierci długoletniego prezydenta kraju Félixa Houphouët-Boigny'ego, doszło do znacznie trwalszego, niż na Madagaskarze, podziału terytorium kraju. Brak „ojca narodu” doprowadził do rozpadu partii rządzącej Demokratycznej Partii WKS (PDCI), z której w 1982 r. wydzielił się Front Ludowy (FPI) (Konarski 2004). U źródła konfliktu legła frustracja muzułmańskiej ludności północy kraju, od lat pozbawianej wpływu na rządy. W wyborach prezydenckich 2000 r. kandydatem Północy był Alessane Ouatarra, ale nie został dopuszczony do wyborów z powodu miejsca urodzenia jego ojca w byłej Górnej Wolcie (Kirwin 2006, s. 47). Specjalnie zmieniono w tym celu artykuł 35 konstytucji WKS. Niezadowoleni muzułmanie z Północy dokonali, we wrześniu 2002 r., nieudanej próby zamachu stanu, po której jako Nowe Siły szybko opanowali Północ kraju, doprowadzając do jego podziału. Przy mediacji Francji podpisano w Marcoussis, 24 stycznia 2003 r., warunki pokoju przewidujące usunięcie kontrowersyjnego artykułu z konstytucji, rozbrojenie Nowych Sił i reformy demokratyczne. 
Przywódcy Północy i prezydent WKS mieli się zmierzyć w wyborach prezydenckich w 2005 r., a do czasu ich przeprowadzenia strony konfliktu miały pozostać rozdzielone strefą neutralną, kontrolowaną przez siły pokojowe ONZ, głównie wojska francuskie (ryc. 12). Powstała faktycznie międzynarodowa linia demarkacyjna dzieląca kraj od zachodu na wschód na dwie części.

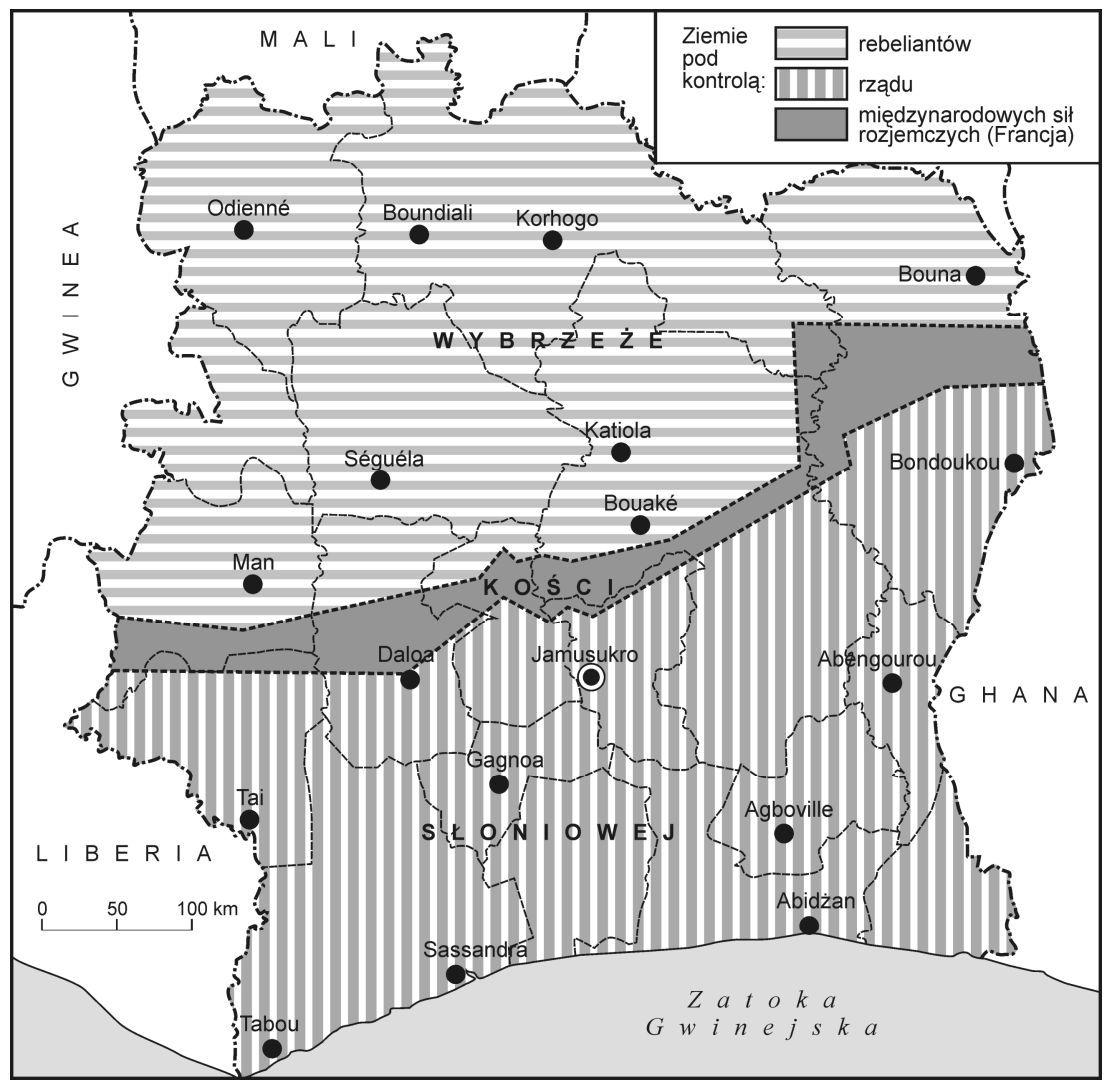

Ryc. 12. Podział Wybrzeża Kości Słoniowej w trakcie wojny domowej z lat 2002-2007 Źródło: opracowanie własne na podstawie: First Ivorian... (2015)

Rebelianci nie potrafili skutecznie zarządzać Północą i doprowadzili ją do ruiny ekonomicznej, natomiast prezydent Południa sabotował ogłoszenie wyborów, wobec czego nie doszło do rozbrojenia Nowych Sił. Wojska rządowe Południa 4 listopada 2004 r. zaczęły ofensywę na Północ, lotnictwo bombardowało największe miasta regionu Bouaké i Korhogo, nie zważając, że w ataku ucierpiały też siły pokojowe. W odpowiedzi Francja dokonała silnych ataków lotniczych z bazy w Gabonie, niszcząc całkowicie lotnictwo sił rządowych. W Abidżanie doszło do ataków bojówek prorządowych na Europejczyków, 
których wojska francuskie musiały przesiedlić w kolejnej akcji zbrojnej. W ewakuacji ok. 8 tys. białych z WKS uczestniczyły wojska Wielkiej Brytanii, Hiszpanii i Kanady.

Kryzys zażegnała Unia Afrykańska, skłaniając obie strony do rokowań zakończonych porozumieniem w Abidżanie 6 grudnia 2004 r. Pomimo że mandat prezydenta WKS wygasał 30 października 2005 r., nie zamierzał on rozpisać wyborów. Unia Afrykańska zgodziła się na jego przedłużenie o rok. Kolejny rok dołożyła RB ONZ, zwiększając jednak uprawnienia premiera WKS kosztem prezydenta. Układ pokojowy z Nowymi Siłami zawarto dopiero 4 marca 2007 r., a ich przywódca został premierem WKS.

Wybory prezydenckie udało się odwlec aż do listopada 2010 r. Zmierzył się w nich urzędujący prezydent WKS Laurent Gbagbo i tym razem dopuszczony kandydat Północy - Alessane Ouatarra. Wynik ogłoszony przez komisję wyborczą wskazywał na zwycięstwo Ouatarry. Rządzący Front Ludowy zaskarżył wynik wyborów do Rady Konstytucyjnej, wskazując na liczne fałszerstwa w komisjach na Północy (nie potwierdzali ich obserwatorzy ONZ, ale dostrzegali obserwatorzy Unii Afrykańskiej) (Owgang 2011). Opanowana przez zwolenników Gbagbo, Rada Konstytucyjna uznała odwołanie i ogłosiła jego zwycięstwo przewagą $51 \%$ głosów. Ouatarra twierdził, że zdobył 54\%, co potwierdzała ONZ i międzynarodowa opinia licznych państw świata. Obaj kandydaci zorganizowali w Abidżanie inaugurację prezydentury, przy czym Gbagbo nie miał w tym poparcia międzynarodowego. Wojna domowa w WKS mogła zostać wznowiona.

Mediację w imieniu Unii Afrykańskiej podjął Thabo Mbeki, były prezydent RPA, a RB ONZ uznała za legalnego prezydenta Ouatarrę. WKS zostało zawieszone w prawach członka Unii Afrykańskiej i Wspólnoty Gospodarczej Państw Afryki Zachodniej. Trwanie prezydenta Gbagbo na urzędzie doprowadziło w latach 2010-2011 do wybuchu w WKS drugiej wojny domowej. Walki objęły Douékoué i Bloléquin. W tej sytuacji siły międzynarodowe i wojska francuskie podjęły działania przeciwko siłom Gbagbo, aresztując uzurpatora 11 kwietnia 2011 r. w jego rezydencji. Prezydent Alessane Ouatarra wezwał do odbudowy zniszczonego kraju i ogłosił jego ponowne zjednoczenie po dziewięciu latach podziału (Bah 2012, s. 6). Siły pokojowe nadal stacjonują w WKS, ale linia demarkacyjna oddzielająca Północ od Południa została zniesiona.

Bardzo budujące, w stosunkach pomiędzy państwami afrykańskimi, jest rozstrzygnięcie sporu granicznego pomiędzy Botswaną a Namibią o wyspę Sedudu (Kasikili) na granicznej rzece Chobe, który oba państwa 15 lutego 1976 r. zdecydowały przekazać pod arbitraż Międzynarodowego Trybunału w Hadze (Alexander 1999, s. 321). Wyrok z 13 grudnia 1999 r. przyznawał sporną wyspę o powierzchni $5 \mathrm{~km}^{2}$ Botswanie. 
Trzecim przypadkiem w Afryce pokojowego rozwiązania sporu granicznego jest konflikt Nigerii z Kamerunem o półwysep Bakassi, położony w estuarium rzeki Cross, na Wybrzeżu Calabarskim. Od czasu objęcia brytyjską protekcją kolonialną w 1884 r. wodzów Akwa Akpa, całe wybrzeże wokół Calabaru stało się posiadłością brytyjską, ale granicy wschodniej nigdy nie wyznaczono. Pozwoliło to objąć administracją nigeryjską cały półwysep Bakassi.

Dokumenty przedstawione przez stronę kameruńską, oparte na umowie brytyjsko-niemieckiej o podziale posiadłości, wskazują na przynależność półwyspu do Niemiec, a zatem do Kamerunu Zachodniego. Ponieważ ten również do 1960 r. był pod administracją brytyjską, nikt nie podnosił kwestii przebiegu granicy w bagnistej okolicy. Kiedy na skutek referendum w 1961 r. Kamerun Zachodni przyłączono do Nigerii, półwysep Bakassi pozostał w regionie Calabar należącym w Nigerii. Od 1981 r. oba państwa weszły w spór dotyczący przebiegu wspólnej granicy na półwyspie i nad jeziorem Czad. Na początku lat 90. XX w. doszło nawet do starć zbrojnych.

W tej sytuacji 29 marca 1994 r. Kamerun skierował spór do Międzynarodowego Trybunału Sprawiedliwości w Hadze. Sprawa była złożona prawnie, gdyż obie strony argumentowały swoje roszczenia na podstawie dokumentów kolonialnych, które zarówno one, jak i współczesna społeczność uznają za nielegalne z punktu widzenia prawa międzynarodowego. Dodatkowo przywołano dwie umowy pomiędzy stronami sporu - Drugą Deklarację z Jaunde z 4 kwietnia 1971 r. i Deklarację z Maroua z 1 czerwca 1975 r., które normują przebieg morskiej granicy pomiędzy Nigerią i Kamerunem, już po uzyskaniu przez nie niepodległości. Granicę przeprowadzono przez estuarium rzeki Cross, na zachód od spornego półwyspu, co oznacza jego przynależność do Kamerunu. Jednak Nigeria nigdy nie ratyfikowała tych umów, a Kamerun uznawał je za obowiązujące de facto. Wyrok MTS z 10 października 2002 r. był korzystny dla Kamerunu (przesądziły umowy brytyjsko-niemieckie) (ryc. 13). Polecono Nigerii przekazać półwysep, ale nie zmuszać jego mieszkańców do przemieszczenia się lub zmiany obywatelstwa, co wywołało konsternację w kraju. Nigeria odmówiła wykonania wyroku i wycofania swoich wojsk z Bakassi. Ponieważ ONZ uznał wyrok MTS za obowiązujący, groziło to sankcjami wobec Nigerii.

Dzięki mediacji Kofi'ego Annana zwołano trójstronny szczyt przywódców i powołano mieszaną komisję dla rozwiązania sporu granicznego. Kolejny szczyt z 31 stycznia 2004 r. przyniósł pewne porozumienie, ale wówczas opór stawili mieszkańcy półwyspu Bakassi, którzy nie zgadzali się na przeniesienie do Kamerunu (Tarlebbea, Baroni 2010, s. 207).

Na spotkaniu w Nowym Jorku prezydenci Nigerii i Kamerunu, przy mediacji ONZ, zawarli 16 czerwca 2006 r. porozumienie. Nigeria zgodziła się, w ciągu 60 dni, wycofać swoje wojska z półwyspu i przekazać go Kamerunowi (Nigeria 
hands... 2006). Wykorzystując fakt, że Nigeria zrzekła się suwerenności nad półwyspem Bakassi, lokalni politycy proklamowali 2 lipca 2006 r. secesję z Nigerii - Demokratycznej Republiki Bakassi, którą miały wspierać Organizacja Ludów Południowego Kamerunu (SCAPO), Ruch na rzecz Samostanowienia Bakassi (BAMOSD) i Ruch na rzecz Wyzwolenia Delty Nigru (MEND).

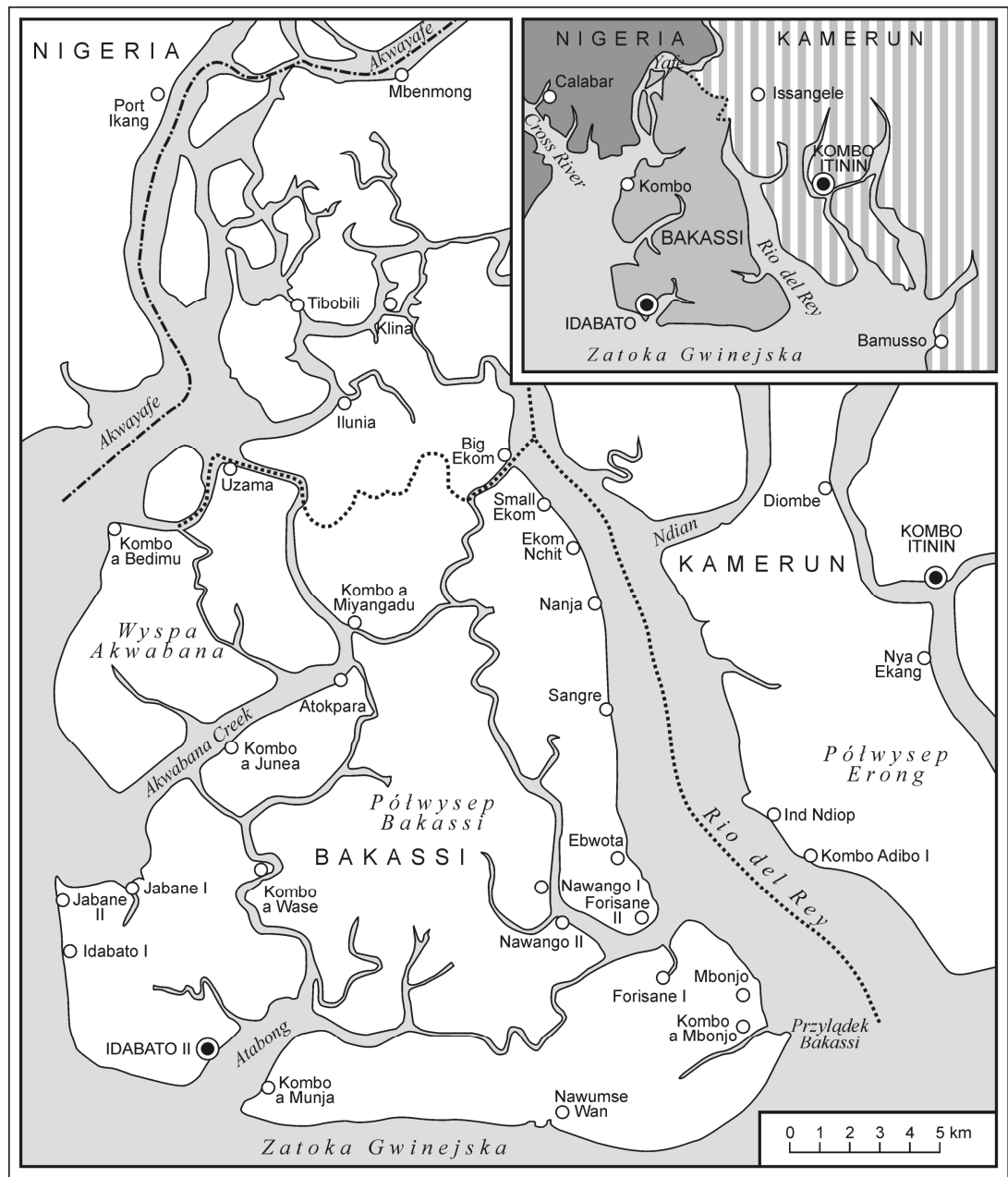

Ryc. 13. Spór graniczny Nigerii z Kamerunem o półwysep Bakassi Źródło: opracowanie własne na podstawie: N. Omoigui (2007), Bakassi (2015)

Pomimo że senat Nigerii 22 listopada 2007 r. stwierdził nielegalność zrzeczenia się suwerenności nad Bakassi, rząd nigeryjski się nie ugiął i 14 sierpnia 2008 r. przekazał półwysep Kamerunowi. Sąd Najwyższy uznał ten akt za słuszny, acz przedwczesny, gdyż należało najpierw zadbać o interes rybackiej ludno- 
ści regionu. Pomimo przejęcia półwyspu przez Kamerun, jest on nadal w wykazie samorządów w Nigerii stanowiącej załącznik do konstytucji z 1999 r. Odbywają się tam również nigeryjskie wybory. Tym sposobem w Afryce dokonała się na drodze legalnej i pokojowej, choć nie bezproblemowo, trzecia zmiana przebiegu granicy międzynarodowej (Baye 2010, s. 11).

Czwarta pokojowa zmiana granicy nastąpiła, gdy Benin 10 sierpnia $2007 \mathrm{r}$. objął w posiadanie, na skutek realizacji wyroku MTS z 12 lipca 2005 r., dziewięć wysepek na granicznych z Nigrem rzekach Mekrou i Niger, o łącznej powierzchni $60 \mathrm{~km}^{2}$. Ceremonia przekazania terytorium miała miejsce na wysepce Tondi Kwara Barou. Największą z wysp Lété i 16 mniejszych przyznano Nigrowi (Walther 2015, s. 698).

Piątym wypełnieniem wyroku MTS było przekazanie Nigrowi, 17 lutego 2008 r., przez Nigerię osiedla rybackiego Tomba Mota, należącego dotąd do dystryktu Abadam w stanie Borno. Mieszkańcy osiedla, w liczbie 3 tys., mieli prawo wyboru pozostania w nim jako obywatele Nigru lub zachowania obywatelstwa nigeryjskiego, ale $\mathrm{z}$ koniecznością przeniesienia się na terytorium Nigerii.

Najnowszym konfliktem w Afryce, choć też mającym dawne źródła i kolejne etapy rozwoju, jest wojna domowa w Mali, czyli konflikt rządu tego państwa i Azawadu. Region konfliktu to pogranicze kilku państw w centrum Afryki (Mali, Nigru, Algierii i Libii), na styku Sahary i Sahelu, w wielkim oddaleniu od morza, choć o strategicznym znaczeniu. Pozwala kontrolować ważny szlak handlowy znad Morza Śródziemnego do Zatoki Gwinejskiej i Afryki Równikowej, a także sąsiaduje bezpośrednio z jednymi z najważniejszych dla świata złożami uranu w północnym Nigrze oraz ważnymi polami wydobycia ropy naftowej i gazu ziemnego w południowej Algierii i Libii.

Obszar Mali, na którym toczy się walka, to zasadniczo trzy północne prowincje kraju: Timbuktu, Kidal i Gao oraz północna część prowincji Mopti. Zatem łączna powierzchnia Azawadu stanowi ok. 860 tys. $\mathrm{km}^{2}$ i zamieszkuje go 2,2 mln mieszkańców (w 2009 r.), obecnie zapewne nieco mniej na skutek ucieczki części ludności.

Na populację tej części Mali składa się kilka dominujących grup etnicznych: Songhaj, Fulbeje z osiadłej grupy Bantu, rasy negroidalnej oraz Tuaregowie, nomadyczny lud berberyjski pochodzenia chamito-semickiego, rasy europeidalnej. Nie ma natomiast w Azawadzie różnic religijnych, niemal wszyscy są muzułmanami (odmiennie niż na południu Mali, gdzie Bantu bywają też chrześcijanami).

Tuaregowie zostali podbici przez Arabów w VII w., przyjęli islam, zachowując jednak własny język tamaszek, zapisywany pismem tifinagh, oraz odrębne obyczaje, m.in. monogamię. Byli spychani przez Arabów na coraz bardziej nie- 
urodzajne ziemie, na Saharę, która stała się ich terytorium, ale wkrótce ją przekroczyli, utrzymując łączność karawanową pomiędzy Afryką Północną i Subsaharyjską. Granice zamieszkanych przez nich terytoriów wyznaczono w $1884 \mathrm{r}$. na konferencji berlińskiej, gdzie dzielono posiadłości europejskich metropolii w Afryce. Jednak efektywnie ziemie Tuaregów były kolonizowane przez Francję dopiero w XX w., w praktyce aż do lat 30. Do tego czasu Tuaregowie nie podlegali jurysdykcji obcych władz. Również współcześnie zachowali dużą rezerwę wobec podziałów politycznych, nie respektując granic państwowych i nie ubiegając się o żadne obywatelstwo.

Ziemie Azawadu należały w historii do wielkich imperiów afrykańskich Gao w IX w., Mali XIV-XV w. i Timbuktu (Songhaj) od XVI w. Okresowo w XVIIXVIII w. byli podbijani przez Sułtanat Marokański, ale generalnie zachowywali niezależność aż do kolonizacji francuskiej (efektywnie w 1893 r.) (Tymowski 1979, s. 189).

Na obszarze Mali, Algierii, Nigru i Libii Tuaregowie wzniecali często powstania zbrojne. W Mali większe powstania trwały w latach 1914-1917 (główne walki toczono w Nigrze), 1962-1964, 1990-1995, 2007-2009 i od 2012 r. Celem powstań była zazwyczaj poprawa warunków ekonomicznych oraz, wraz z narastaniem świadomości politycznej, poszerzenie praw aż do autonomii, a nawet secesji.

Wkrótce po uzyskaniu niepodległości przez Mali (1960 r.) na północy kraju ujawniły się napięcia społeczne, gdy populacja pustynnych części Mali i Nigru oraz południowych saharyjskich regionów Algierii i Libii nie doczekała się spodziewanej państwowości. W 1962 r. wybuchło w północnym Mali powstanie Tuaregów, zwane Alfellaga, które nie było kierowane przez żadną organizację polityczną, a jedynie oparte na strukturach plemienno-klanowych (Keita, Henk 1998, s. 10). Nowa armia malijska szybko spacyfikowała powstanie, bojownicy uciekli na Saharę Algierską, wówczas jeszcze francuskie terytorium wojskowe (Calvocoressi 2002, s. 649).

Kontynuacją rebelii na obszarze północnych regionów Nigru i Mali było powstanie z lat 1990-1995. Jego celem była autonomia terytorialna, a nawet niezależność, ale u podłoża ekonomicznego leżała długotrwała susza na Sahelu i utrata stad bydła, które nie zostały skompensowane przez dotacje rządowe. Stronami konfliktu były armie rządowe Mali i Nigru oraz wspierająca je milicja Ghanda Koi ludu Songhaj. Oba państwa były osłabione tą samą suszą, zdane na międzynarodową pomoc finansową, a politycznie zdestabilizowane puczami, które obaliły legalne władze. Po stronie powstania walczyły w Mali: Arabski Islamski Front Azawadu (FIAA), Ludowy Ruch Wyzwolenia Azawadu (MPLA), Zjednoczony Ruch i Front Azawadu (MFUA). W Nigrze powstanie wznieciły: Front Wyzwolenia Airu i Azaouaku (FLAA), Front Wyzwolenia Tamoust (FLT) 
oraz koalicja Skoordynowany Opór Zbrojny (CRA) i Organizacja Zbrojnego Oporu (ORA) (Santos 2003, s. 10). Sojusznikiem powstańców w tym konflikcie była Libia rządzona przez prezydenta Mu'ammara al-Kaddafiego. Dobrze uzbrojone i zorganizowane siły powstańcze starły się z osłabionymi armiami państw, z którymi walczyły, toteż konflikt był znacznie dłuższy. W Mali walki toczyły się wokół Gao. Po zmianie władz w Mali Tuaregowie uzyskali na mocy porozumienia z Tamanrasset z 6 stycznia $1991 \mathrm{r}$. autonomię w regionie Kidal i obietnicę szybszej ich integracji z ludnością kraju (Keita, Henk 1998, s. 16). Po raz pierwszy więc powstała tuareska jednostka polityczna wyznaczona granicą.

Jednak knowania libijskie, zbrojenie i trenowanie w obozach libijskich nowych oddziałów doprowadziły w 1994 r. do wznowienia walk. Na tym etapie konfliktu armię rządową Mali wsparła milicja ludu Songhaj (Ghanda Koi), co oznaczało już wojnę domową i to umiędzynarodowioną przez udział Libii (Keita, Henk 1998, s. 20). Od 1995 r. rozpoczęły się rokowania pokojowe, które zaowocowały zawarciem pokoju i ceremonialnym paleniem broni w Timbuktu w 1996 r. Rząd obiecał sprawiedliwy podział międzynarodowej pomocy humanitarnej, także pośród Tuaregów, a ci zrezygnowali z separatyzmu.

Następny konflikt z udziałem Tuaregów w Mali i Nigrze wybuchł w lutym 2007 r. W Mali powstańców reprezentował ruch Maj 23 (2006) - Demokratyczny Alians na rzecz Zmian oraz Tuareski Alians Nigru i Mali na rzecz Zmian (ATMNC), a w Nigrze walczyły: Nigerski Ruch dla Sprawiedliwości (NMJ), Front Sił dla Naprawy (FFR) i Nigerski Front Patriotyczny (NPF).

Do Mali i Nigru powrócili w tym czasie z Algierii i Libii uchodźcy polityczni, bojownicy poprzednich powstań i zasilali lokalne milicje tuareskie. Dwudziestego września 2007 r. Tuareska Partia Narodowa (TNP) proklamowała niepodległość federacyjnej Republiki Amazighe Tumoujgha (Kraj Tuareski), obejmującej północno-wschodnią część Mali (połowę państwa) i północno-zachodni Niger (2/3 kraju) (Les Imazighen... 2009). Niektóre źródła podawały, że twórcy republiki wysuwali roszczenia terytorialne także wobec Libii i Algierii. Republika miała charakter konfederacji siedmiu plemion: Haggar, Ajjer, Aïr, Azawagh, Adghagh, Tadamakkat, Oudalan, a stolicą miał być Agadez w Nigrze. Walki skoncentrowały się w malijskim regionie Kidal i nigerskim Agadez. Przy mediacji Algierii, w sierpniu 2008 r., udało się wynegocjować rozejm z Mali, ale w grudniu jedna $\mathrm{z}$ frakcji powstańczych powróciła do walki (Brody 2011).

W Nigrze sytuacja była bardzo groźna, bo powstańcy zbliżyli się do kopalni uranu, ale pośrednictwo Libii doprowadziło do zawarcia rozejmu w maju 2009 r. W końcowej fazie konfliktu pojawiły się informacje o prawdopodobnym wsparciu powstańców przez al-Kaidę.

Najnowsza faza konfliktu zbrojnego w Mali rozpoczęła się 17 stycznia 2012 r., kiedy Narodowy Ruch Wyzwolenia Azawadu (MNLA) wzniecił ko- 
lejne powstanie przeciw Mali. Celem była niepodległość państwa tuareskiego. Walki objęły północną część Mali, a sprzyjały im kłopoty wewnętrzne w armii rządowej po dokonanym puczu wojskowym. Wykorzystując destabilizację Mali, Tuaregowie ogłosili 6 kwietnia 2012 r. niepodległość Republiki Azawadu (Déclaration ... 2012), obejmującej trzy północne prowincje Mali - Timbuktu, Kidal i Gao oraz fragment prowincji Mopti, ale zapowiadając respektowanie granic zewnętrznych kraju, co było nowością, bo poprzednie proklamacje tuareskie głosiły powstanie jednostek transgranicznych, obejmujących terytoria państw sąsiednich (ryc. 14). Unie Afrykańska i Europejska nie uznały tej proklamacji (Olivier de Sardan 2013, s. 39).

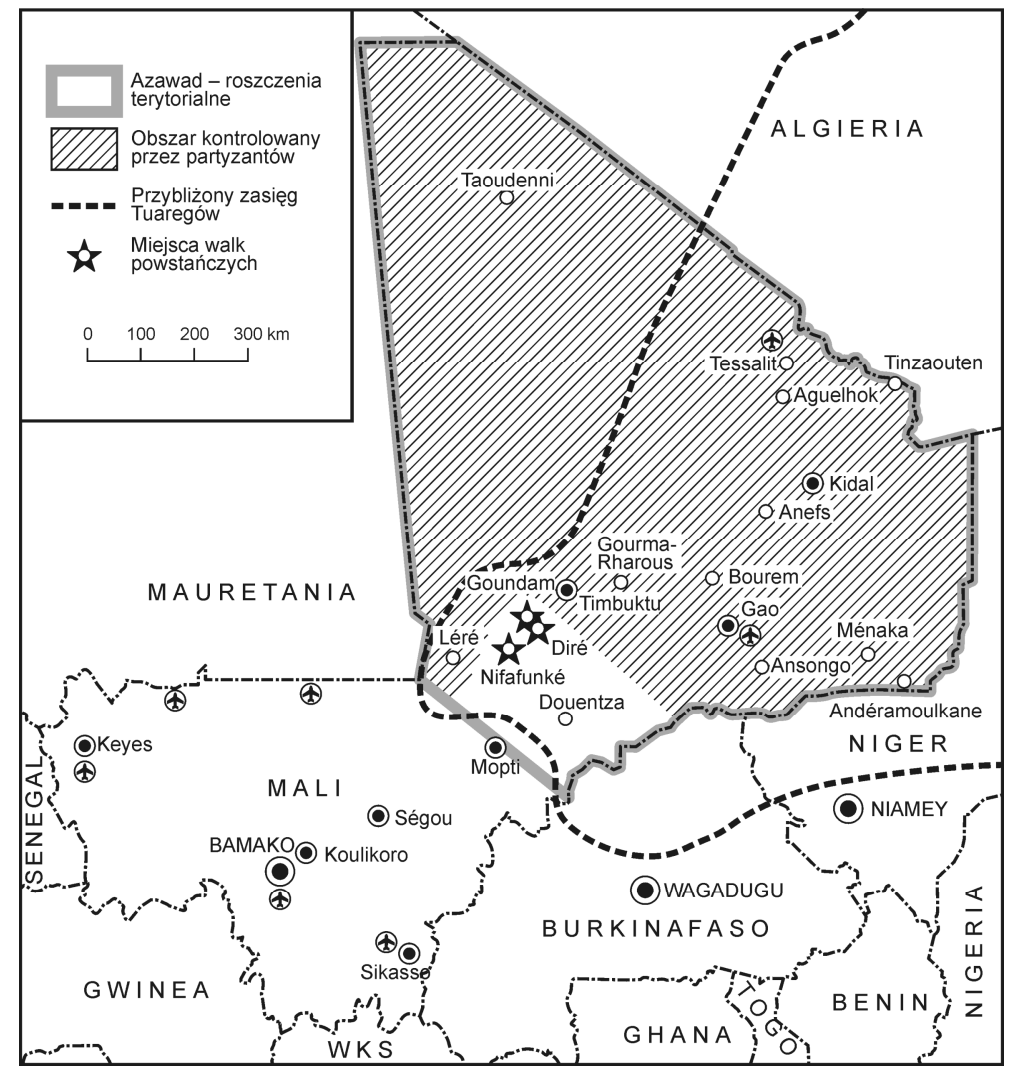

Ryc. 14. Secesja Azawadu w Mali 2012-2013

Źródło: opracowanie własne na podstawie: D. Alvarado (2012)

Proklamowanie własnego państwa miało charakter propagandowo-polityczny, gdyż bardzo szybko niepodległościowy ruch tuareski zdominowany został przez islamistyczną organizację Ansar Dine, założoną w marcu 2012 r. przez weterana powstań tuareskich Lyad Ag Ghaly, obecnie powiązanego z al-Kaidą 
Islamskiego Maghrebu (AQIM) (Olivier de Sardan 2013, s. 37). Celem Ansar Dine nie jest niepodległość państwa tuareskiego, lecz ustanowienie szariatu w całym Mali. Deklaracja niepodległości uzyskała wprawdzie akceptację Ansar Dine 12 maja 2012 r., gdy ogłoszono nową nazwę państwa - Islamska Republika Azawadu, ale bardzo szybko różnica celów strategicznych doprowadziła do wycofania poparcia dla niepodległości przez fundamentalistów islamskich, a od czerwca 2012 r. nawet do walk pomiędzy oboma ugrupowaniami, z których zwycięsko wyszli islamiści. Tuarescy powstańcy Azawadu zostali zepchnięci na peryferie i utracili kontrolę nad wszystkimi ważnymi ośrodkami. Islamiści zajęli 27 czerwca stolicę Azawadu Gao, a 12 lipca ostatnie miasto Ansongo, zdobywając niepodzielną władzę nad większością Azawadu, gdzie wprowadzili szariat. Zamieszkujący północne Mali Arabowie także nie są zwolennikami niepodległości i utworzyli Front Wyzwolenia Narodowego Azawadu (FLNA), mając na myśli wyzwolenie spod okupacji tuareskiej (Alvarado 2012, s. 54).

Niezdolne do obrony swego terytorium Mali zwróciło się z prośbą o pomoc międzynarodową. Udzieliła jej ONZ, a Francja wysyłała 11 stycznia 2013 r. do Mali znaczne siły zbrojne. Swoje wojska przysłały też państwa Unii Afrykańskiej i NATO (lotnictwo brytyjskie, kanadyjskie, a wparcia logistycznego udzieliła też Polska). Kluczową bitwą było odzyskanie 11 stycznia 2013 r. opanowanej już przez islamistów Konny, $600 \mathrm{~km}$ od Bamako. Błyskawiczna ofensywa wojsk alianckich 8 lutego osiągnęła granicę z Algierią koło Tessalit - ostatniego punktu oporu islamistów. Rebelianci, choć pokonani militarnie, prawdopodobnie zdołali zachować zdolność dalszej walki, gdyż rozpierzchli się w trudno dostępnym terenie lub schronili w pozbawionej kontroli władz części Libii, Nigru i Algierii (Francis 2013, s. 3).

Rozejm pomiędzy rebeliantami Tuareskimi a rządem Mali zawarto 18 czerwca 2013 r., ale już 26 września powstańcy się z niego wycofali, twierdząc, że rząd nie dotrzymuje jego warunków. Na jaw wyszły zbrodnie armii malijskiej dokonywane na cywilach pod osłoną wojsk francuskich. Ostatecznie układ pokojowy zawarto w Algierze 19 lutego 2015 r., ale sporadycznie nadal dochodzi do lokalnych starć.

Siódma i jak dotąd ostatnia pokojowa zmiana przebiegu granic w Afryce ma miejsce na granicy Nigru i Burkina Faso, na skutek wyroku Międzynarodowego Trybunału Sprawiedliwości z 16 kwietnia 2013 r. (Bourkina... 2015). Oba państwa zwróciły się o arbitraż MTS 20 lipca 2010 r. w sprawie sporu o odcinek granicy pomiędzy Tong Tong a Botou długości $998 \mathrm{~km}$. Na mocy decyzji trybunału Niger otrzymał $277 \mathrm{~km}^{2}$ spornego obszaru, a Burkina Faso aż $786 \mathrm{~km}^{2}$. Oba kraje muszą dokonać wymiany dotąd administrowanymi obszarami na wspólnej granicy, przy czym wymienionych zostanie 18 osiedli. Większość z nich, bo 14 otrzyma, Burkina Faso (ryc. 15). Wymianę zaczęto w maju 2015 r. 
i ma się ona zakończyć do końca roku. Jak zauważył rzecznik Ministerstwa Sprawiedliwości Nigru Maru Amadou, przebieg granicy, którą w 1926 r. wyznaczyli nie-Afrykanie, teraz uzgadniają sami Afrykanie. Aż trzecia część granic Burkiny Faso z jej sąsiadami nadal nie została delimitowana.

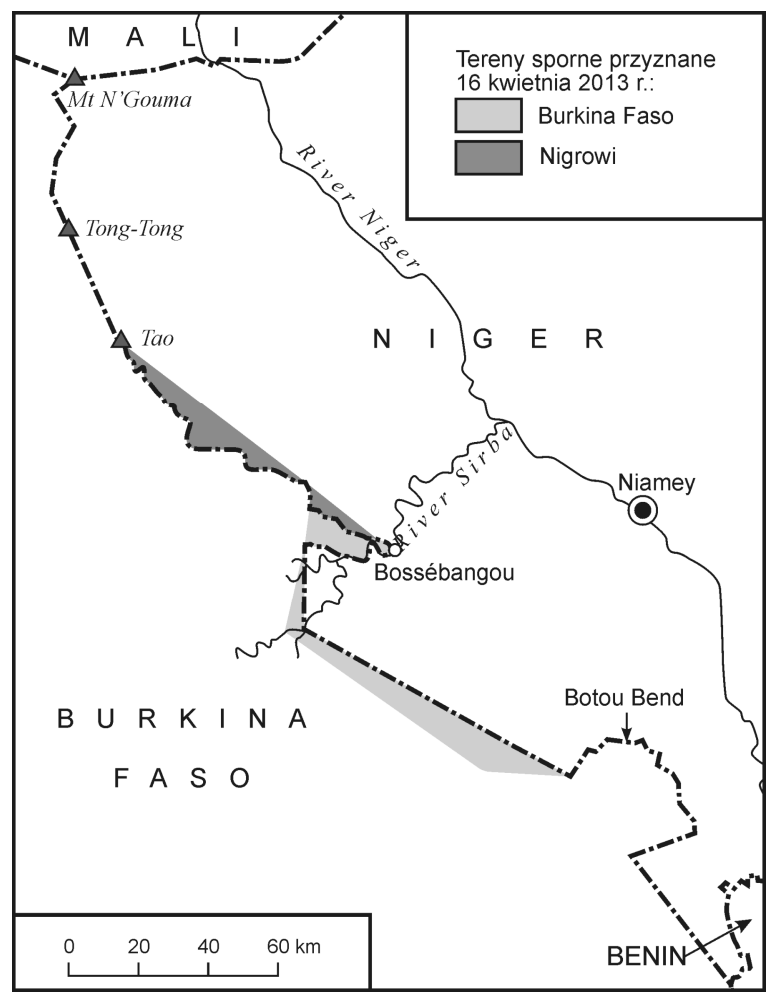

Ryc. 15. Spór graniczny Nigru z Burkina Faso i jego rozstrzygnięcie w 2013 r. Źródło: opracowanie własne na podstawie: E. Centanni (2013)

Państwa afrykańskie coraz częściej korzystają z arbitrażu Międzynarodowego Trybunału Sprawiedliwości. Trzynastego lipca 2015 r. spór o przebieg granicy morskiej skierowały do trybunału Kenia i Somalia. Te zaś państwa, które wyrok już otrzymały, najczęściej się do niego stosują, a przekazanie terytoriów odbywa się w sposób uroczysty, tak aby podkreślić dobrą wolę utrzymania poprawnych stosunków z sąsiadem.

\subsection{Afryka Północna}

W latach 2010-2013 w arabskich państwach Afryki Północnej doszło do masowych wystąpień społeczeństw przeciw lokalnym dyktaturom. Ten zapoczątkowany w Tunezji proces objął wszystkie państwa regionu, ale w Maroku 
doprowadził jedynie do zmian konstytucyjnych, a w Algierii do niewielkiej demokratyzacji. Tylko w trzech pozostałych państwach zmiany ustrojowe były znaczące. W Tunezji udało się nie tylko obalić dyktaturę, ale także zaimplementować demokrację, choć terroryzm i niepokoje u sąsiadów pogorszyły położenie geopolityczne kraju. W Libii i Egipcie obalenie dyktatur wywołało wybuch walk zbrojnych z islamistami i walk plemiennych, które w Egipcie doprowadziły do obalenia quasi-demokratycznego rządu islamistycznego przez armię i ustanowienia kolejnej dyktatury. Egipt stał się również państwem niestabilnym.

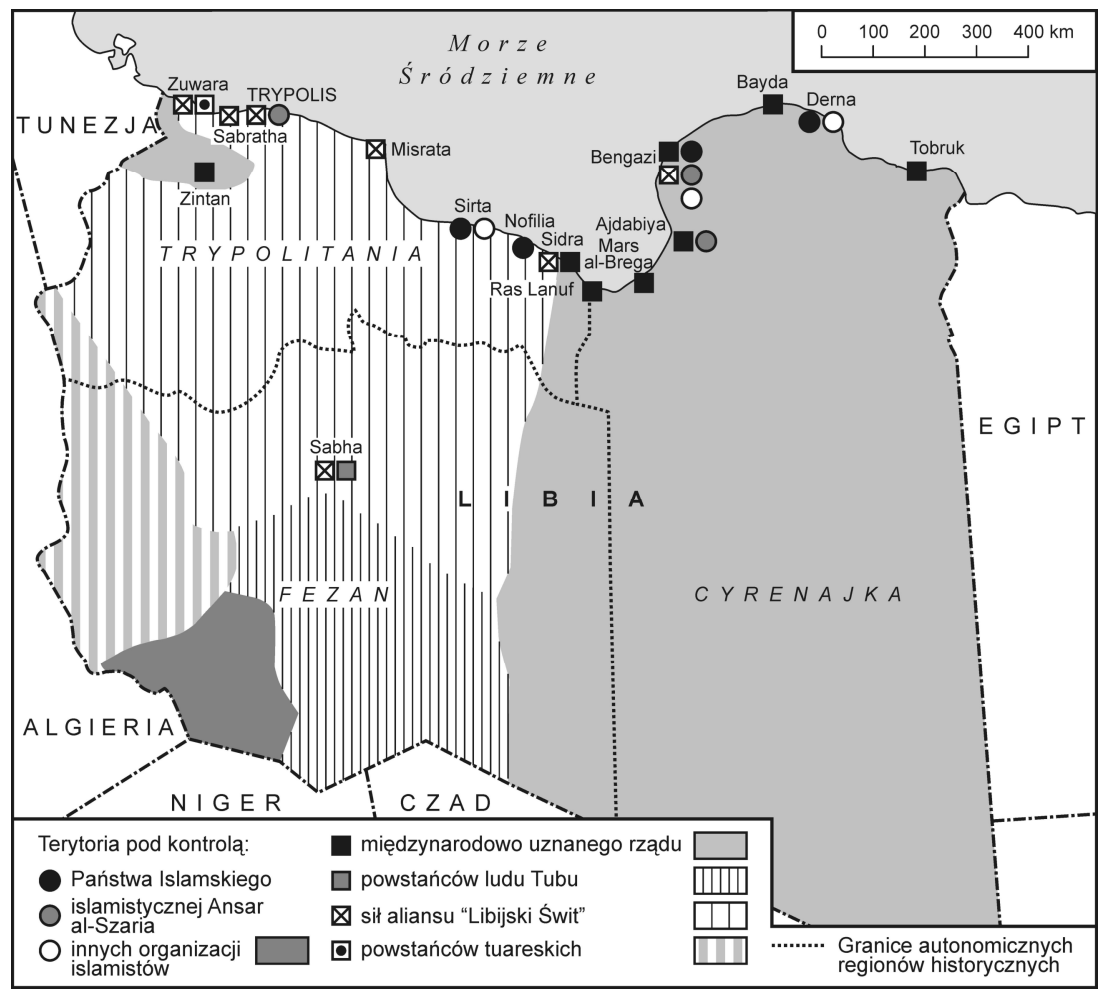

Ryc. 16. Podział polityczny Libii na tle prowincji historycznych w 2015 r. Źródło: opracowanie własne na podstawie: Libya violence... (2015)

Libia natomiast popadała w wojnę domową, w trakcie której odtworzył się podział na dawne prowincje. W czasie rewolucji ,arabskiej wiosny” w $2011 \mathrm{r}$. przeciwnicy dyktatury Kaddafiego opanowali Cyrenajkę, podczas gdy Trypolitania była matecznikiem sił reżimowych. W 2015 r., kiedy w Libii trwa wojna pomiędzy siłami, które obaliły dyktaturę, ale różniącymi się stosunkiem do roli islamu w życiu państwa, w Cyrenajce rezyduje demokratycznie wyłoniony parlament i rząd, a siły islamistyczne opanowały głównie Trypolitanię. Jednak 
w najnowszym konflikcie dawne granice polityczne nie odzwierciedlają już przestrzennej kontroli terytorium przez poszczególne strony konfliktu, gdyż również Fezzan i duża część zachodniej Cyrenajki są obecnie (listopad 2015) pod kontrolą islamistów (Libya violence... 2015) (ryc. 16).

\section{Konkluzje}

Analiza zmian granic w Afryce po drugiej wojnie światowej pozwala na ustalenie kilku prawidłowości. Jak się okazuje, zmienność granic jest względnie duża, jednak znakomita większość zmian polega na zmianie rangi granicy (jej wzroście lub degradacji w hierarchii granic politycznych). Było to związane początkowo, jeszcze $\mathrm{w}$ okresie kolonialnym, z procesami integracji posiadłości kolonialnych $\mathrm{w}$ federacje kolonii, następnie ich dezintegracji na niepodległe państwa, a po $1960 \mathrm{r}$. ponownej integracji, już dobrowolnej, i to nie zawsze odtwarzającej byłe federacje kolonialne. Pojawiły się też procesy dezintegracji poprzez secesję regionów, w już niepodległych państwach afrykańskich, zazwyczaj dokonujące się w toku wojny domowej, a zatem nielegalne, z których tylko dwie zakończyły się uznaniem międzynarodowym państw dokonujących secesji (Erytrea i Sudan Południowy). Znacznie rzadsze były zmiany granic w ich podstawowym rozumieniu, czyli zmiany przebiegu granicy $\mathrm{w}$ terenie. Takie zmiany też zachodziły w wyniku wojen granicznych, zazwyczaj nie miały charakteru trwałego i z reguły nie zyskały międzynarodowej akceptacji.

Najrzadziej dochodziło do legalnych zmian granic międzynarodowych, na drodze umów pomiędzy zainteresowanymi stronami i wymiany terytoriów. Zasadniczo tylko pierwsza taka zmiana, pomiędzy Mali i Mauretanią, odbyła się całkowicie dobrowolnie i bez obcego pośrednictwa. Pozostałe cztery już dokonane zmiany granic najczęściej poprzedził ostry spór międzynarodowy, prowadzący niekiedy do zbrojnych starć granicznych, a uzyskanie porozumienia odbywało się na drodze arbitrażu organizacji międzynarodowych, najczęściej Międzynarodowego Trybunału Sprawiedliwości w Hadze.

Taka struktura zmian granic w Afryce dowodzi, że nadal respektowana jest zasada, że granic państw afrykańskich nie należy zmieniać, choć ich kształt i proces delimitacji przeważnie nie jest dziełem Afrykanów, tylko dziedzictwem kolonialnym. Żadne względy: etniczne, kulturowe, historyczne, polityczne, a tym bardziej ekonomiczne, nie są wystarczające, aby dopuścić do zmian granic nimi usprawiedliwianych. Siłowa próba zmiany granic spotyka się z międzynarodowym potępieniem, w czym Afryka nie jest wyjątkiem, nawet jeśli zmiana ta jest częściowo oparta na umowach międzynarodowych (przypadek Sahary Zachodniej), a agresor jest zazwyczaj wykluczany ze społeczności państw kontynentu (Unii Afrykańskiej). 
Poza istniejącymi granicami de iure pojawiają się w Afryce liczne granice de facto, często dzielące państwa na dwie albo i większą liczbę odrębnych jednostek politycznych, których byt jest mniej lub bardziej trwały (niektóre istnieją ponad ćwierć wieku).

Całkowicie odrębnym zagadnieniem jest istnienie w Afryce granic nieformalnych, przeważnie przedkolonialnych, wyznaczających terytoria plemienne zorganizowane w monarchie, których władcy nadal panują, za cichą zgodą rządów państw republikańskich, na obszarze których funkcjonują (np. Aszanti w Ghanie, Ankole w Ugandzie) (Sobczyński 2006, s. 504-518). Dla Południowej Afryki specyficzne jest istnienie granic państw plemiennych, niemających jednak podstaw w dziedzictwie historycznym, tylko sztucznie kreowanych w procesie rasistowskiej polityki segregacji terytorialnej. Granice takie znane są jeszcze tylko z Ameryki i Australii (rezerwaty indiańskie i aborygeńskie).

Spośród 54 państw afrykańskich, w 15 występują tendencje separatystyczne (Algieria, Angola, D.R. Konga, Etiopia, Kenia, Libia, Mali, Maroko, Nigeria, Senegal, Somalia, Sudan, Tanzania, Zambia i Zimbabwe) (Fisher 2012). Brak stabilności granic afrykańskich objawia się dużą liczbą sporów granicznych, przeradzających się niekiedy $\mathrm{w}$ starcia zbrojne. Niestabilność wewnętrzna państw ma też przełożenie na funkcjonowanie ich granic, które stają się strefą napięć. Dodatkowym problemem jest kumulacja w strefach pograniczy, w bezpośredniej bliskości granic, wielkiej liczby uchodźców politycznych, żyjących w tymczasowych obozach i obciążających i tak już niewydolne systemy ekonomiczne tych państw (Sobczyński 2003, s. 146).

Ja wykazują badania Africa Border Monitor (2015), państwa kontynentu są silnie zróżnicowane pod względem wielkości współczynnika niestabilności granic. Duża ich stabilność (indeks poniżej 3) występuje w państwach Afryki Południowej (na południe od D.R. Konga, Zambii i Tanzanii) oraz w nadmorskich państwach Afryki Zachodniej od Maroka po Benin i w trzech nadmorskich państwach Afryki Równikowej (Kongo, Gwinea Równikowa i Gabon). Obszary silnej niestabilności to Afryka Północna, Wschodnia i Środkowa. Szczególnie wysokim współczynnikiem przekraczającym 33 wyróżniają się Libia, Maroko i Nigeria (ryc. 17).

Spośród 166 granic międzynarodowych w Afryce 17 jest absolutnie hermetycznych, nie ma na nich żadnych przejść granicznych. Szczególna pod tym względem jest sytuacja Gwinei Równikowej, która nie ma przejścia granicznego na żadnej ze swoich granic lądowych (w części kontynentalnej kraju Mbini). Na kolejnych 11 granicach zamknięte jest co najmniej jedno przejście graniczne (Africa Border... 2015). Obywatele wszystkich państw afrykańskich muszą mieć paszport, jeśli chcą wjechać do jakiegokolwiek innego państwa swojego kontynentu, co w dobie znoszenia restrykcyjności granic jest już ewenementem. 


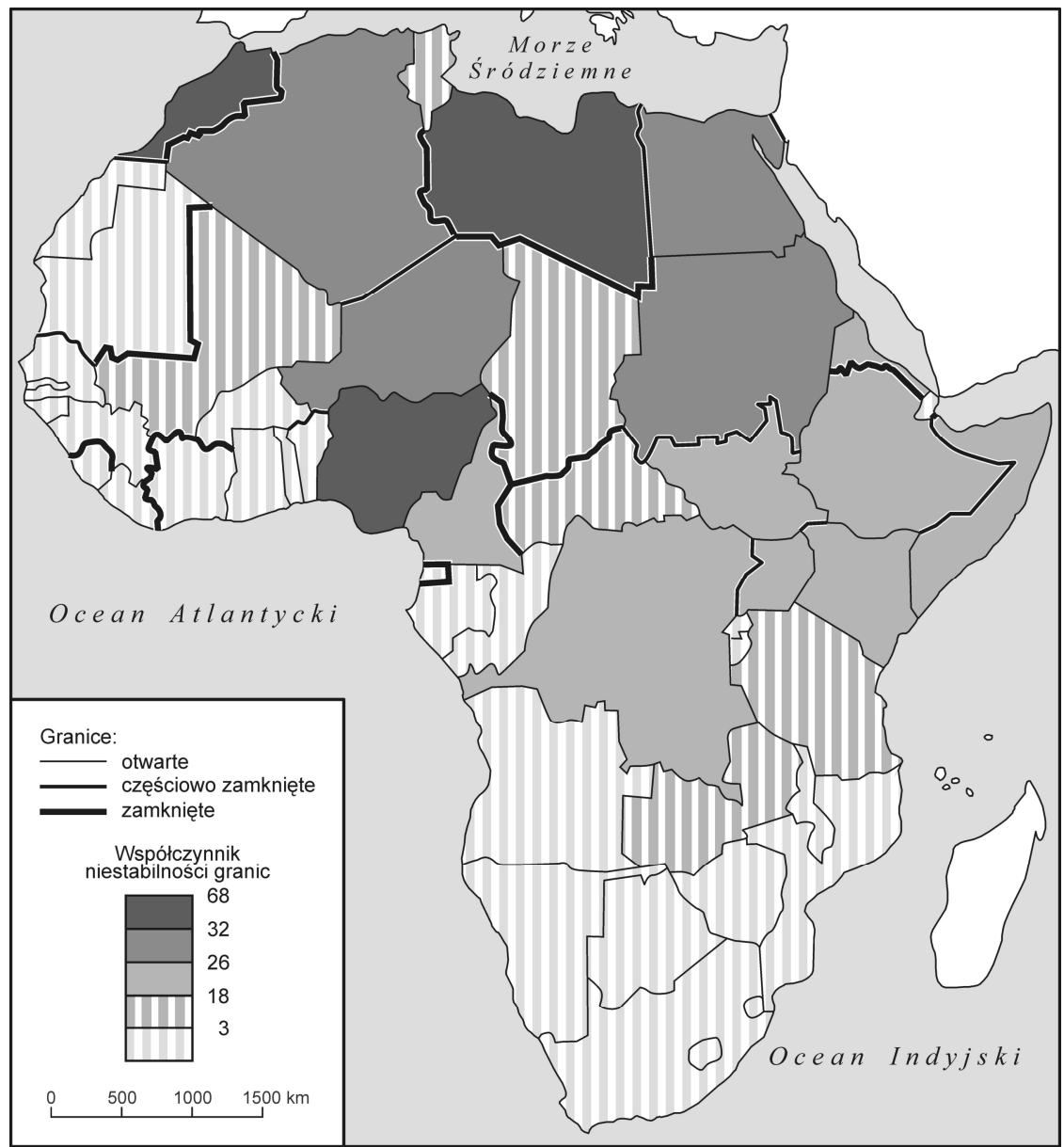

Ryc. 17. Przepuszczalność granic państw afrykańskich i współczynnik ich niestabilności

Źródło: opracowanie własne na podstawie:

Africa Border Monitor (2015)

Afrykańskie granice dzielą ponad 177 grup etnicznych, ale gdyby każdej grupie etnicznej, także tej niepodzielonej granicą, przyznać prawo do państwowości, to w Afryce byłoby ok. 2 tys. państw (Mungai 2015). Fakt ten ilustruje nierealność prawa do samostanowienia dla każdej grupy etnicznej w Afryce i wymusza politykę koegzystencji w ramach takich jednostek geopolitycznych, które są zdolne do funkcjonowania w społeczności międzynarodowej, nie tylko w sensie politycznym, ale także militarnym, a przede wszystkim gospodarczym. 


\section{Literatura}

Africa Border Monitor, 2015: http://www.africabordermonitor.com/ (18.08. 2015).

Africa South of the Sahara, 2004, Regional surveys of the World, vol. 33, London.

Alexander W.J.R., 1999, Science, history and the Kasikili Island dispute, „South African Journal of Science", 95 (8), s. 321-325.

Alvarado D., 2012, Independent Azawad. Tuaregs, jihadists, and uncertain future of Mali, Barcelona.

American dad stakes claim to African kingdom of 'North Sudan' so his daughter can become a princess, 2014, „The Independent”, 14.07.:

http://www.independent.co.uk/news/world/americas/ (17.08.2014).

Amrani I., 2012, Sudan: SAS on Heglig and Abyei, „The Arabist”:

http://arabist.net/blog/2012/4/30/ sudan-sas-on-heglig-abyei.html (26.08. 015).

Arab League calls on Eritrea pull out of Djiboutian border areas, 2008, KUNA Kuwait News Agency, June 12:

http://www.kuna.net.kw/ArticleDetails.aspx?id=1916310\&language=en (16.08.2015).

Awdal "Republic": declaration of independence, (Somalia), 2007, African Studies Center, University of Pennsylvania:

http://www.africa.upenn.edu/Hornet/awdal.html (14.08.2015).

Bah T.M., 2012, Addressing Côte d'Ivoire's deeper crisis, Washington.

Bakassi, 2015, Wikipedia: https://pt.wikipedia.org/wiki/Bakassi (26.08.2015).

Baye F.M., 2010, Implications of the Bakassi conflict resolution for Cameroon, „African Journal of Conflict Resolution", 10 (1), s. 9-34.

Boniface P., 2001, Atlas wojen XX wieku. Konflikty współczesne i w przyszłości, Warszawa.

Border war with Ethiopia, 2015, Global security. Military:

http://www.globalsecurity.org/military/world/ war/eritrea.htm (27.08.2015).

Bourkina Faso and Niger exchange 18 towns to settle border dispute, 2015, „The Guardian", 8.05.:

http://www.theguardian.com/world/2015/may/08/ (18.08.2015).

Brody H., 2011, Gaddafi and the Tuareg, the "Lords of the desert", Open Democracy: http://www.opendemocracy.net/hugh-brody/ (17.08.2015).

Calvocoressi P., 2002, Polityka międzynarodowa 1945-2000, Warszawa.

Centanni E., 2013, Niger and Burkina Faso resolve territorial dispute, Political Geography Now, Updates of the changing of world map:

http://www.polgeonow.com/2013/04/niger-burkina-faso-disputed-territory.html (26.08.2015).

Coleman S., 2002, Mad for Marc, „World Press Review”, 49 (4):

http://www.worldpress.org/africa/ 0402madagascar.htm (16.08.2015).

Czarnecki M., 2015, Sudańskie jądro ciemności, „Gazeta Wyborcza”, 199, 27.08, s. 8.

Déclaration d'Indépendance ee l'Azawad, 2012, Mouvement National de libération de l'Azawad: http://www.mnlamov.net/component/content/article/169-declaration-dinde pen dance-de-lazawad.html (26.08.2015). 
Djiboutian-Eritrean border conflict, 2015, Wikipedia:

https://en.wikipedia.org/wiki/Djiboutian\%E2\%80\%93Eritrean_border_conflict (27.08. 2015).

Domański P., 1999, Dżibuti, [w:] Mantel-Niećko J., Ząbek M. (red.), Róg Afryki. Historia państw świata $w X X$ wieku, Warszawa, s. 333-363.

Elmi A., 2015, Decentralized unitary system: a possible middle-ground model for Somalia, Doha.

Eritrean-Ethiopian war, 2015, Wikipedia: https://en.wikipedia.org/wiki/ Eritrean \%E2\% 80\%93Ethiopian_War (27.08.2015).

Federal gov't, leaders sign new agreement to form Hiiraan and Middle Shabelle State, 2015, Hiiraannet.com.: http://www.hiiraannet.com/ (14.05.2015).

First Ivorian civil war, 2015, Wikipedia: https://en.wikipedia.org/wiki/First_Ivorian_ Civil_War (26.08.2015).

Fisher M., 2012, The dividing of a continent: Africa's separatist problem, „The Atlantic”, 10.10.: http://www.theatlantic.com/international/archive/2012/09 (18.08. 2015).

Francis D.J., 2013, The regional impact of the armed conflict and French intervention in Mali: http://www.peacebuilding.no/ var/ezflow_site/storage/ original/application/f18 726c3338e39049bd4d554d4a22c36.pdf (26.08.2015).

Hanlon J., Waterhouse R., 1995, Renamo held 23\% of land (1995), „Mozambique Peace Process Bulletin", 14, s. 6.

Hartleb-Wroczyńska D., 1999, Powstanie państwa erytrejskiego, [w:] Mantel-Niećko J., Ząbek M. (red.), Róg Afryki. Historia państw świata w XX wieku, Warszawa, s. 235284.

Hirad A., 2013, Jubaland State of Somalia: a model state to Somalia, Wardheer News, May 19: http://cdn.wardheernews.com/wp-content/uploads/2013/05/ (25.08.2015).

Hoehne M.V., 2007, Puntland and Somaliland clashing in Northern Somalia: who cuts the gordian knot?, Horn of Africa, Social Science Research Council: http://hornofafrica.ssrc.org/Hoehne/printable.html (13.08.2015).

Hoehne M.V., 2015, Between Somaliland and Puntland. Marginalization, militarization and conflict political visions, Contested borderlands, London:

http://www.riftvalley.net/ download/file/fid/3719 (25.08.2015).

Huntington S., 1993, Clash of civilizations, „Foreign Affairs”, Summer, s. 22-49.

Keita K., Henk D., 1998, Conflict and conflict resolution in the Sahel: the Tuareg insurgency in Mali, Washington.

Kirwin M., 2006, The security dilemma and conflict in the Cote d'Ivoire, „Nordic Journal of African Studies", 15 (1), s. 42-52.

Konarski M., 2004, Geneza i przebieg konfliktu na Wybrzeżu Kości Stoniowej, Portal Spraw Zagranicznych. Opinie: http://www.psz.pl/124-polityka/ (16.08.2015).

Kurcz M., 2008, Sudańska mozaika. Sytuacja etniczna $w$ wioskach nad Nilem między III a IV katarakta, ,Sprawy Narodowościowe”, 32, s. 135-148.

Les Imazighen Touaregs déclarent la naissance de la Republique Amazighe Tumoujgha, 2009, Amazigh World:

http://www.amazighworld.org/human_rights/index_show.php?id=1146 (26.08.2015). 
Libya violence: Islamic State attack 'kills 40' in al-Qubbah, 2015, BBC News, February 20: http://www.bbc.com/news/world-africa-31549280 (1.08.2015).

Łykowska L., 1999, Etiopia od lipca 1991 do 1998 roku, [w:] Mantel-Niećko J., Ząbek M. (red.), Róg Afryki. Historia państw świata w XX wieku, Warszawa, s. 203-234.

Madagascar: Govt denies witch hunt for pro-Ratsiraka supporters, 2003, IRIN Humanitarian news and analysis: http://www.irinnews.org/report/42305/ (16.05.2015).

Malaquias A., 2000, Ethnicity and conflict in Angola: prospects for reconciliation, [w:] Angola's war economy, Pretoria, s. 95-113.

Mantel-Niećko J., 1999, Etiopia od początku dziejów do 1991 roku, [w:] Mantel-Niećko J., Ząbek M. (red.), Róg Afryki. Historia państw świata w XX wieku, Warszawa, s. 183-201.

Mareeg State, 2015, Wikipedia Insaykalobeedhiya Xorta ah: https://so.wikipedia.org/wiki/Mareeg_State (14.08.2015).

Massey S., Baker B., 2009, Comoros: external involvement in a small island state, Programme Paper, July, AFP 2009/1, London.

Mesfin B., 2008, The Eritrea-Djibouti border dispute, Situation Report, September 15, Pretoria.

Morland A., 2014, Analysis: the state of state-building in Somalia, IRIN Humanitarian news and analysis: http://www.irinnews.org/report/100745/ (14.05.2015).

Mungai Ch., 2015, Africa's borders split over 177 ethnic groups, and their 'real' lines aren't where you think, ,Mail and Guardian Africa”, 13.01.:

http://mgafrica.com/article/ (17.08.2015).

Namibia. Facts and figures, 1991, Windhoek.

Nigeria hands Bakassi to Cameroon, 2006, BBC News, 14.08.: http://news.bbc.co.uk/2/hi/africa/4789647.stm (17.08.2015).

Olivier de Sardan J.-P., 2013, The „,Tuareg question” in Mali today, „Cahiers du Mapinduzi", 3 (1), s. 28-41: www.bu.edu/wara/.../mali-the-Tuareg-question.pd (26.08.2015).

Omoigui N., 2007, The Bakassi story, Postwatch.com the undiluted truth: http://www.postwatchmagazine.com/2007/10/the-bakassi-sto.html (26.08.2015).

Orłowska I., 1999, Historia Somalii do 1991 r., [w:] Mantel-Niećko J., Ząbek M. (red.), Róg Afryki. Historia państw świata w XX wieku, Warszawa, s. 285-308.

Owgang T., 2011, The root causes of the conflict in Ivory Coast, Africa Portal: https://www.africaportal.org/dspace/articles/ (16.08.2015).

Peace agreements: Eritrea-Ethiopia, 2000, Washington: http://www.usip.org/publications/peace-agreements-eritrea-ethiopia (25.08. 2015).

Podeszwa G., 1999, Historia Somalii po upadku rzadu Siada Barre, [w:] Mantel-Niećko J., Ząbek M. (red.), Róg Afryki. Historia państw świata wXX wieku, Warszawa, s. 309-331.

Polity IV Country Report: Djibouti, 2010, Vienna, VA: www.systemicpeace.org/polity (16.08.2015).

Puntland. Fact and figures, 2003, Garoowe.

Saleh Bali M., 1996, Somaliland: an introduction, „Hargejsa Somaliland Alternative Press", 3 (Winter 1996/1997), Somaliland CyberSpace:

http://www.mbali.info/bali04.htm (12.08.2015). 
Santos S.E., 2003, The Tuareg: place and people in self-determination. A politico-economic analysis, Bloomington.

Seibert G., 2003, The vagaries of violence and power in post-colonial Mozambique, [w:] Abbink Gerrit J., Brujin M. de, Walraven K. van (red.), Rethinking resistance: revolt and violence in African history, African dynamic, Leiden, s. 253-276.

Sobczyński M., 2003, Borderlands in Africa as an asylum for war and political refugees [w:] Heffner K., Sobczyński M. (red.), The role of ethnic minorities in border regions, vol. 2: Selected problems of ethnic and religious minorities, Region and Regionalism, No. 6, Łódź-Opole, s. 143-154.

Sobczyński M., 2006, Państwa i terytoria zależne. Ujęcie geograficzno-polityczne, Torun.

Sobczyński M., 2012, Pokój i bezpieczeństwo w skali globalnej, [w:] Trzepacz P. (red.), Zrównoważony rozwój - wyzwania globalne. Podręcznik dla uczestników studiów doktoranckich, Kraków, s. 213-290.

Somali civil war, 2015, Wikipedia: https://en.wikipedia.org/wiki/Somali_Civil_War (18.08.2015).

Somalia report, 2015: http://www.somaliareport.com/ (18.08.2015).

Somalia: al-Shabaab - it will be a long war, 2014, „Policy Briefing. Africa Briefing”, 99, 26.06, International Crisis Group Working to Prevent Conflict Worldwide: http://www.crisisgroup.org/ /media/Files/africa/horn-of-africa/somalia/b099-somalia -al-shabaab-it-will-be-a-long-war.pdf (25.08.2015).

Somalia: Puntland's punted polls, 2013, „Africa Briefing”, 97, International Crisis Group Working to Prevent Conflict Worldwide:

http://www.crisisgroup.org/ /media/Files/africa/horn-of-africa/somalia/b097somalia-puntlands-punted-polls.pdf (25.08.2015).

South Sudan: a civil war by any other name, 2014, „Africa Report”, 217, April 10, International Crisis Group Working to Prevent Conflict Worldwide:

http://www.crisisgroup.org/en/regions/africa/horn-of-africa/south-sudan/217-southsudan-a-civil-war-by-any-other-name.aspx. (25.08.2015).

Stankiewicz W., 2005, Wielopłaszczyznowość konfliktu w Sudanie i perspektywy jego rozwiązania, „Sprawy Narodowościowe”, 26, s. 97-114.

Sudan and South Sudan's top 8 border disputes, 2012, Political Geography Now, Updates of the changing of world map: http://www.polgeonow.com/2012/05/featuresudan-south-sudan-border_26.html (26.08.2015).

Sudan's spreading conflict (I): War in South Kordofan, 2013, „Africa Report”, 198, International Crisis Group Working to Prevent Conflict Worldwide:

http://www.crisisgroup.org/en/regions/africa/horn-of-africa/sudan/ (17.08.2015).

Sudan's spreading conflict (II): War in Blue Nil, 2013, „Africa Report”, 204, International Crisis Group Working to Prevent Conflict Worldwide:

http://www.crisisgroup.org/en/regions/africa/horn-of-africa/sudan/ (17.08.2015).

Sudan's spreading conflict (III): The limits of Darfur's peace process, 2014, „Africa Report", 211, International Crisis Group Working to Prevent Conflict Worldwide: http://www.crisisgroup.org/ /media/Files/africa/horn-of-africa/sudan/211-sudan-s-sp reading-conflict-iii-the-limits-of-darfur-s-peace-process.pdf (17.08.2015). 
Tarlebbea N.K., Baroni S., 2010, The Cameroon and Nigeria negotiation process over the contested oil rich Bakassi Peninsula, ,Journal of Alternative Perspectives in the Social Sciences", 2 (1), s. 198-210.

The declaration of Adal State, 2009, Lughya.com:

http://www.lughaya.com/archives/4612 (14.08.2015).

The history of Walvis Bay, 2005, Walvis Bay Online, City Council: http://www.walvisbaycc.org.na/?page_id=56 (12.08.2015)

The military dynamics of South Sudan's civil war, 2014, Enough Forum: http://www.enoughproject.org/files/Military_Dynamics_of_South_Sudan_Civil_War -_Enough_Forum_-_July2014.pdf(26.08.2015).

The political situation in Somalia as of October 2014, 2015, Reddit Mapporn: https://www.reddit.com/r/MapPorn/comments/30iz8e/the_political_situation_in_som alia_as_of_october/(18.08.2015).

Thu T.Q., 2004, The crisis in Darfur: an analysis of its origins and storylines, Alexandria.

Toboła M., 2012, Konflikt między Sudanem a Sudanem Południowym, Biuletyn Opinie Fundacji Aleksandra Kwaśniewskiego Amicus Europae, nr 10, 17.05., Warszawa.

Traditional governance in Somalia. South Central Somalia, 2005, Brief report for the World Bank, Draft report, World Bank, March 28, Washington.

Transfer of Walvis Bay to Namibia Act, 1993, 1994, State President's Office no. 203 of 1993: http://www.saflii.org/za/legis/num_act/towbtna1993313 (12.08.2015).

Tymowski M., 1979, Historia Mali, Wrocław.

Walther O., 2015, Benin-Niger: the Niger-Mekrou rivers and the Lété island, [w:] Brunet-Jailly E. (red.), Border disputes: a global encyclopaedia, ABC-CLIO, Santa Barbara, s. 694-704.

War in Somalia (2006-2009), 2015, Wikipedia: https://en.wikipedia.org (18.08.2015).

Warner J., 2010, Archipelagoes, decolonization and state power, „International Affairs Journal", 5, Winter, s. 39-44.

Warsame I.H., 2002, Puntland press release on the establishment of Southwest State of Somalia, Somalia Watch, Galkayo:

http://www.somaliawatch.org/archivemar02/020403101.htm (12.08.2015).

Wiatrowski P., 1999, Sudan pod rządami fundamentalistów (1989-1995), [w:] Mantel-Niećko J., Ząbek M. (red.), Róg Afryki. Historia państw świata w XX wieku, Warszawa, s. 155-182.

Williams P.D., 2013, AMISOM in transition: the future of the African Union Mission in Somalia, Rift Valley Institute Briefing Paper, 13.02.:

https:/elliott.gwu.edu/sites/elliott.gwu.edu/files/ downloads/ research/williamsp-rviamisom-0213.pdf (25.08.2015).

Ząbek M., 1999, Historia Sudanu do 1989 roku, [w:] Mantel-Niećko J., Ząbek M. (red.), Róg Afryki. Historia państw świata w XX wieku, Warszawa, s. 107-154. 


\section{Border changes in Africa at the turn of the $20^{\text {th }}$ and $21^{\text {st }}$ centuries}

\section{Summary}

The paper presents border changes occurring in Africa in the last decade of the $20^{\text {th }}$ century and the first fifteen years of the $21^{\text {st }}$ century - the period of grand political transformations caused by the disappearance of the bipolar division of the world and the fall of Communism. In Africa, this period was associated with the release of a dozen countries from Soviet domination, the rejection of socialism in economics and the return to free-market capitalism. The principle of the inviolability of African state borders was also questioned. During the period, numerous political border shifts occurred peacefully, with international mediation or by military force, though the latter are still not accepted by the international community and rarely end with long-lasting success.

Keywords: borders, conflicts, international relations, Africa.

Marek Sobczyński, prof. dr hab.

Katedra Geografii Politycznej i Studiów Regionalnych, Wydział Nauk Geograficznych, Uniwersytet Łódzki, 90-142 Łódź, ul. Kopcińskiego 31 